\title{
Provenance of Pleistocene Sediments in West Sarawak and Evidence for Pliocene Acid Magmatism in Central Borneo
}

\author{
H. Tim Breitfeld \\ SE Asia Research Group, Department of Earth Sciences, Royal Holloway University of London, \\ Egham, TW20 OEX, UK \\ Corresponding author: tim.breitfeld@rhul.ac.uk
}

\begin{abstract}
Quaternary deposits in Borneo are commonly not assigned to any formation or group and are usually not studied in great detail but are important for understanding of the Pleistocene to Holocene climate and drainage evolution. This study presents a detrital zircon provenance analysis of two possible (Plio-) Pleistocene fluvial deposits in West Sarawak, indicating two very different source areas and paleo-river drainages. Those paleo-rivers resemble the present-day drainage but show much higher energy level deposits associated with higher sedimentation rates possibly as a function of (Plio-) Pleistocene climate and hinterland exposure. The deposits at Kampung Jangkar in western West Sarawak were entirely sourced by the uplifted Pueh batholith. In contrast, sediments in Petra Jaya district (northern Kuching city) were sourced by recycling of the Kayan Sandstone near the Bungo Range in the area of the town Bau. The Petra Jaya sediments have abundant Pliocene and some Late Miocene zircons. The Niut Volcanics south of West Sarawak are of this age, but are basic and could not yield significant zircons. It is therefore concluded that zircons came from acid igneous rocks of Pliocene age, as well as the Kayan Sandstone and Middle Miocene Bau Suite igneous rocks, where they formed a highland in the Bau-Bungo Range region which has been entirely removed by erosion.
\end{abstract}

Keywords: Sediment provenance, Pliocene, Pleistocene, Kampung Jangkar, Petra Jaya, Sarawak.

\section{INTRODUCTION}

The geological record of southern Sarawak (known as division West Sarawak) and adjacent NW Kalimantan is dominated by sediments in large onshore Cenozoic basins that include the Kayan Group in the west of West Sarawak, the Ketungau Group of the Ketungau Basin stretching across the Sarawak-Kalimantan border and its potential eastern extension in Kalimantan the Mandai Basin, the Melawi Basin with the Suwang, Melawi and Kapuas groups in the south, and the Landak Basin in the southwest of NW Kalimantan (Figure 1)
(Liechti et al., 1960; Doutch, 1992; Heryanto and Jones, 1996; Breitfeld et al., 2018). The sedimentary rocks have an age range from Late Cretaceous (Maastrichtian) to mid-Oligocene (Liechti et al., 1960; Muller, 1968; Pieters et al., 1987; Doutch, 1992; Heryanto and Jones, 1996; Morley, 1998; Hutchison, 2005; Breitfeld et al., 2018) and comprise mostly deltaic and fluviallacustrine deposits with some shallow marineinfluenced packages.

The sedimentary rocks are intruded by stocks and dykes of the Early Miocene Sintang Suite and by 


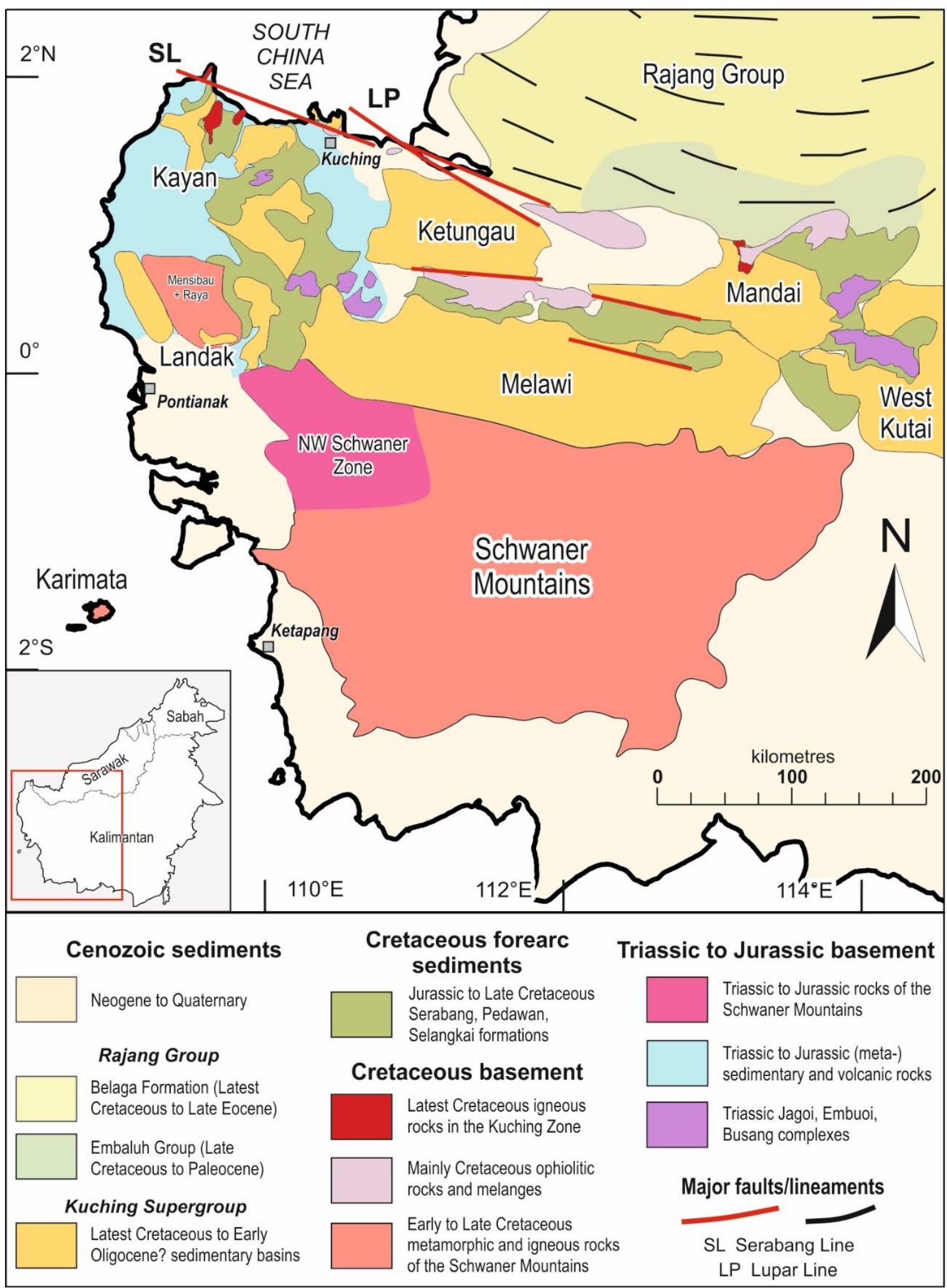

Figure 1: Geological map of western Borneo showing the distribution of Cenozoic sedimentary basins and Mesozoic basement rocks (modified from Breitfeld et al., 2018).

the slightly younger Middle Miocene Bau Suite (Williams and Harahap, 1987; Breitfeld et al., 2019). No sedimentation is recorded in the area from the Oligocene onwards until possibly the end of the Miocene or the Quaternary.
The youngest sedimentary rocks previously reported (e.g., Liechti et al., 1960) were commonly not assigned to formations and were simply described as Quaternary deposits or alluvium, usually exposed in coastal lowland areas. 
Quaternary deposits around the Sunda Shelf include economically important placer deposits (e.g., cassiterite, ilmenite) (Batchelor, 1979; Aleva, 1973, 1985; Jagodzińskia et al., 2020; Nguyen et al., 2020) and can be used to reconstruct climate and sea water level changes (Verstappen, 1980; Voris, 2000; de Bruyn et al., 2014; Solihuddin, 2014; Sathiamurthy and Rahman, 2017; Hantoro, 2018; Wurster et al., 2019).

In recent years many Mesozoic to Cenozoic sedimentary rocks of Borneo have been analysed for their detrital zircon provenance and their drainage has been reconstructed (Witts et al., 2012; van Hattum et al., 2013; Breitfeld et al., 2017; Galin et al., 2017; Breitfeld and Hall, 2018; Hennig-Breitfeld et al., 2019, 2020; Breitfeld et al., 2020a; Burley et al., 2021), but up to now the latest Miocene to Quaternary deposits have not been analysed in detail for provenance or stratigraphic relations, with the exception of the poorly dated upper Neogene Tukau Formation in northern Sarawak (Nagarajan et al., 2017). In West Sarawak no detailed studies of Quaternary deposits to reconstruct their drainage have been undertaken. This study presents results from two locations in West Sarawak where U-Pb ages have been obtained from detrital zircons from possible Pleistocene sedimentary rocks. The successions at the two locations have very different age spectra indicating a different provenance. The youngest detrital zircons also indicate that latest Miocene to Pliocene acid magmatic rocks were a source of sediment, not previously known from central Borneo.

\section{QUATERNARY DEPOSITS IN BORNEO}

Relatively little research has been carried out on Quaternary deposits in Borneo, especially in relation to sedimentology or drainage reconstruction. The area of NW Kalimantan and
West Sarawak commonly referred to as the Kuching Zone (Haile, 1974) is characterised by thick fluvial to deltaic Cenozoic sedimentary sequences in various sedimentary basins (e.g., Doutch, 1992; Breitfeld et al., 2018) with underlying Triassic and Cretaceous igneous and metamorphic basement rocks (Liechti et al., 1960; Williams et al., 1988; Rusmana et al., 1993; Breitfeld et al., 2017; Hennig et al., 2017).

In West Sarawak, the detailed mapping reports of the Malaysian and British Geological Surveys from the 1950's and 60's comment on the distribution, composition, and structure of Quaternary deposits (Figure 2). Usually an 'Older alluvium', or terrace alluvium, and a 'recent' alluvium are described, with a Pleistocene age interpreted for the older deposits (e.g., Wilford, 1959; Liechti et al., 1960; Wolfenden and Haile, 1963; Wilford and Kho, 1965; Tan, 1993). Andriesse (1970) described Quaternary white sand horizons in West Sarawak as a product of leaching and podsolization. These white sand terraces were suggested by Andriesse (1970) to be relics of a large Pleistocene terrace landscape that covered much of Sarawak. Around the town of Sematan, Andriesse (1970) used the terms Pueh, Kilong and Miri series for different possible Pleistocene deposits mapped locally. Those terms, however, are not used much at present. Historically the Quaternary deposits in West Sarawak were mined for alluvial gold and diamonds and therefore had some economic value (Hart Everett, 1913; Wilford and Kho, 1965). White sand terraces called the Jerudong Terrace were also studied from Brunei north of Sarawak (James, 1984).

In NW Kalimantan (Figure 2), adjacent to West Sarawak, Thorp et al. (1990) described the sedimentology of similar white sand terraces of Late Pleistocene age and reported radiocarbon ages of c. $5 \mathrm{ka}$ to $50 \mathrm{ka}$. Thorp et al. (1990) noted that 


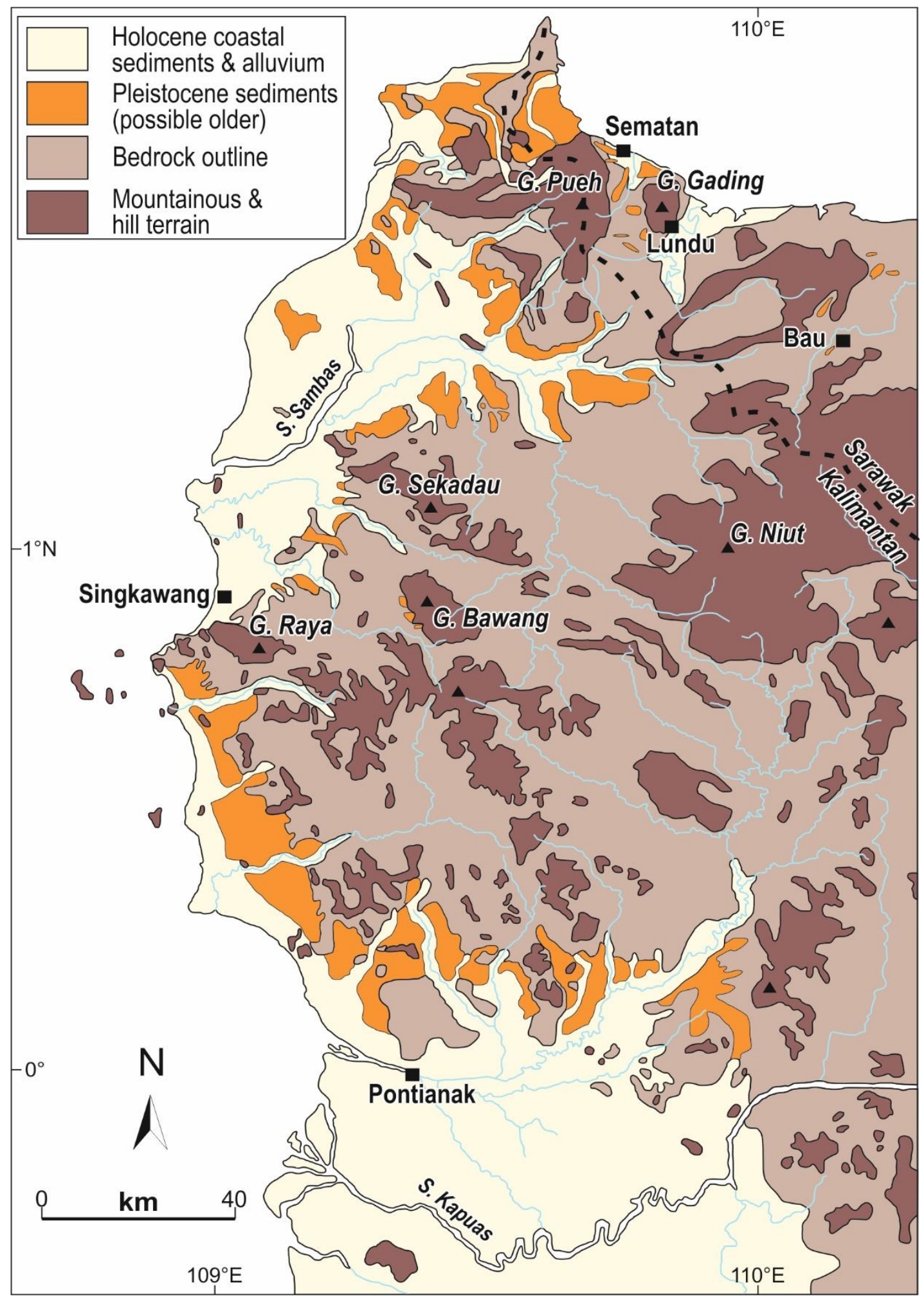

Figure 2: Geomorphology and distribution of Holocene and possible Pleistocene sediments in western Borneo (modified from Thorp et al., 1990). Distribution of Pleistocene sediments in western West Sarawak based on Liechti et al. (1960) and Wolfenden and Haile (1963). Note: although mapped as possible Pleistocene sediments, an extension for some exposures into the Pliocene is also possible. (G-Gunung: mountain, $S$-Sungai: river)

there is no present-day analogue of these fluvial white sand terraces in NW Kalimantan. Although the older Quaternary deposits had been linked to eustatic sea level changes (e.g., Liechti et al., 1960;
Wolfenden and Haile, 1963), Thorp et al. (1990) concluded that tectonic and climate factors must also have contributed to their deposition. Thomas et al. (1999) discussed the white sand horizons and 


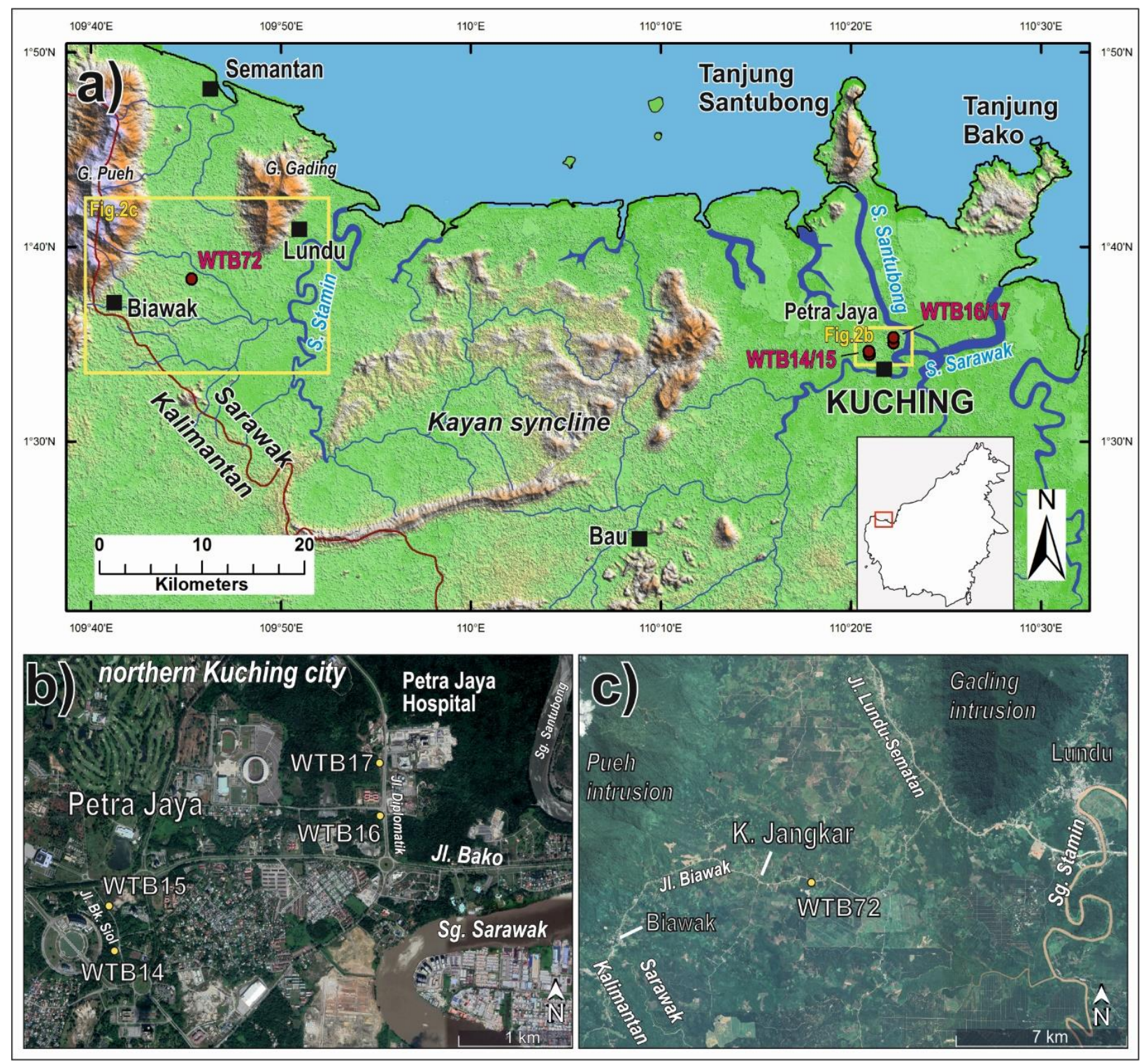

Figure 3: a) SRTM map of western West Sarawak from Kuching to Gunung Pueh, displaying the two sample areas (yellow boxes) in Petra Jaya and near Kampung Jangkar. b) Petra Jaya district in northern Kuching city. c) Kampung Jangkar between the Pueh and Gading Upper Cretaceous intrusions. Detailed sample location maps with reference points from Google Earth, earth.google.com/web/. (Jl - Jalan: road, Tanjung: headland).

interpreted them to have originated by weathering of granodiorites and defined their alluvial distribution in NW Kalimantan.

In SE Kalimantan, research on Pleistocene to Holocene deposits has mostly been concerned with carbon accumulation in peat deposits and climate reconstructions (Page et al., 2004; Morley and Morley, 2011), and Allen and Chambers (1998) presented in detail sedimentological observations of the Miocene and modern-day Mahakam Delta. In northern Borneo, e.g., Collins et al. (2017) reported on the sedimentology of the Miocene to modern-day
Baram Delta in northern Sarawak and Brunei, and Siddiqui et al. (2020) on the sedimentology and reservoir quality of the Mio-Pliocene Sandakan Formation in Sabah.

On the island of Karimata west of southern Borneo (Figure 1), Aleva et al. (1973) identified an older fluvial sedimentary cover of possible Miocene to Pliocene age dissected by an alluvial complex of possible Plio-Pleistocene age. Both units are overlain by a Holocene younger sedimentary cover (Aleva et al., 1973). 


\section{METHODOLOGY}

\section{Fieldwork and Petrography}

Fieldwork in West Sarawak (Figure 3a) was carried out in 2012 in the northern part of Kuching city (Figure 3b), known as district Petra Jaya (WTB14, WTB15), and the roads towards the headlands of Santubong and Bako (WTB16, WTB17), as well as on a road section of Jalan Biawak near the village of Kampung Jangkar (WTB72) in the western part of West Sarawak (Figure 3c). Two sandstone samples were processed and analysed for their detrital zircon ages (TB15b, TB72), and three thin sections (TB14, TB15b, TB72) have been analysed for sandstone petrography from the respective locations, following the method of Gazzi-Dickinson (e.g., Dickinson et al., 1983).
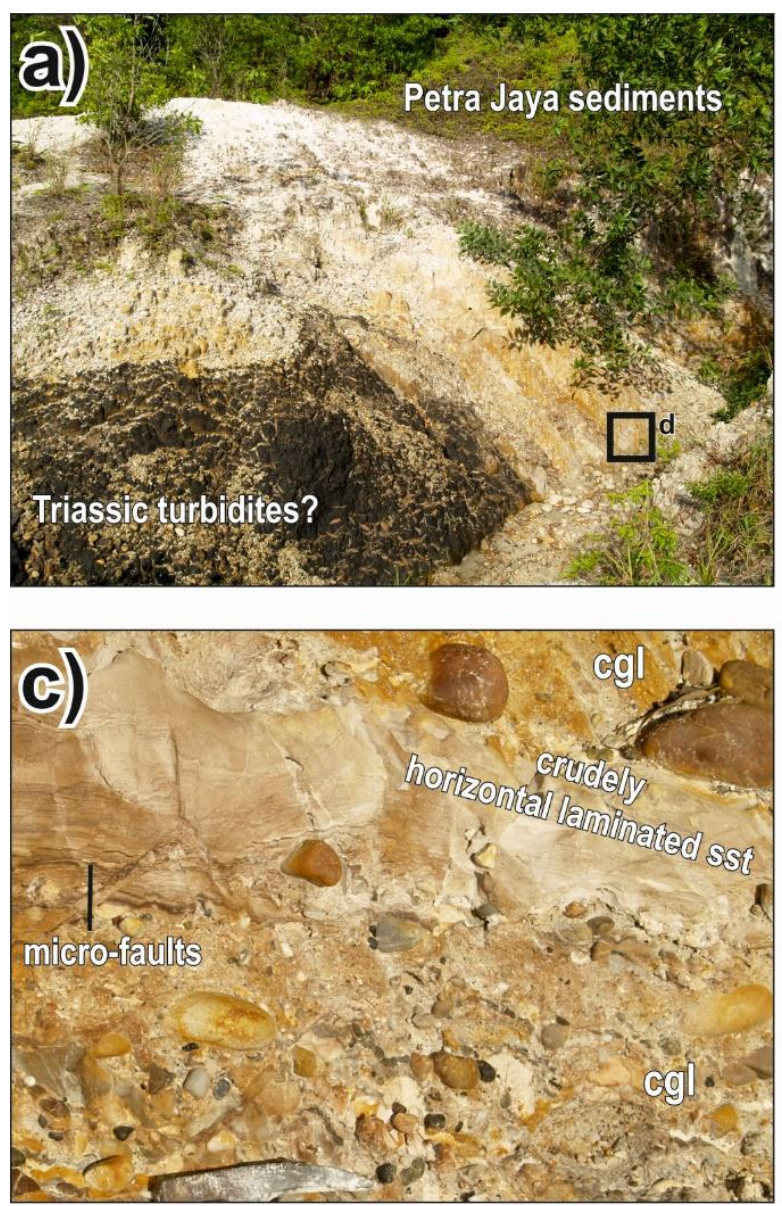

\section{Detrital Zircon Separation and $\mathbf{U}-\mathbf{P b}$ Geochronology}

Sample preparation was carried out at Royal Holloway University of London and followed the methodology outlined in Breitfeld and Hall (2018). A 63-250 $\mu \mathrm{m}$ fraction was chosen for zircon separation. Heavy liquids lithium heteropolytungstate at a density of $2.89 \mathrm{~g} / \mathrm{cm}^{3}$ and di-iodomethane at a density of $3.3 \mathrm{~g} / \mathrm{cm}^{3}$, and a FRANTZ magnetic barrier separator were used to obtain a high purity zircon separate. Zircon grains were imaged in transmitted light to detect cracks or inclusions and under Cathodoluminescence (CL) to identify zoning and guide selection of analysis spots for the laser ablation inductively coupled plasma mass spectrometry (LA-ICP-MS).
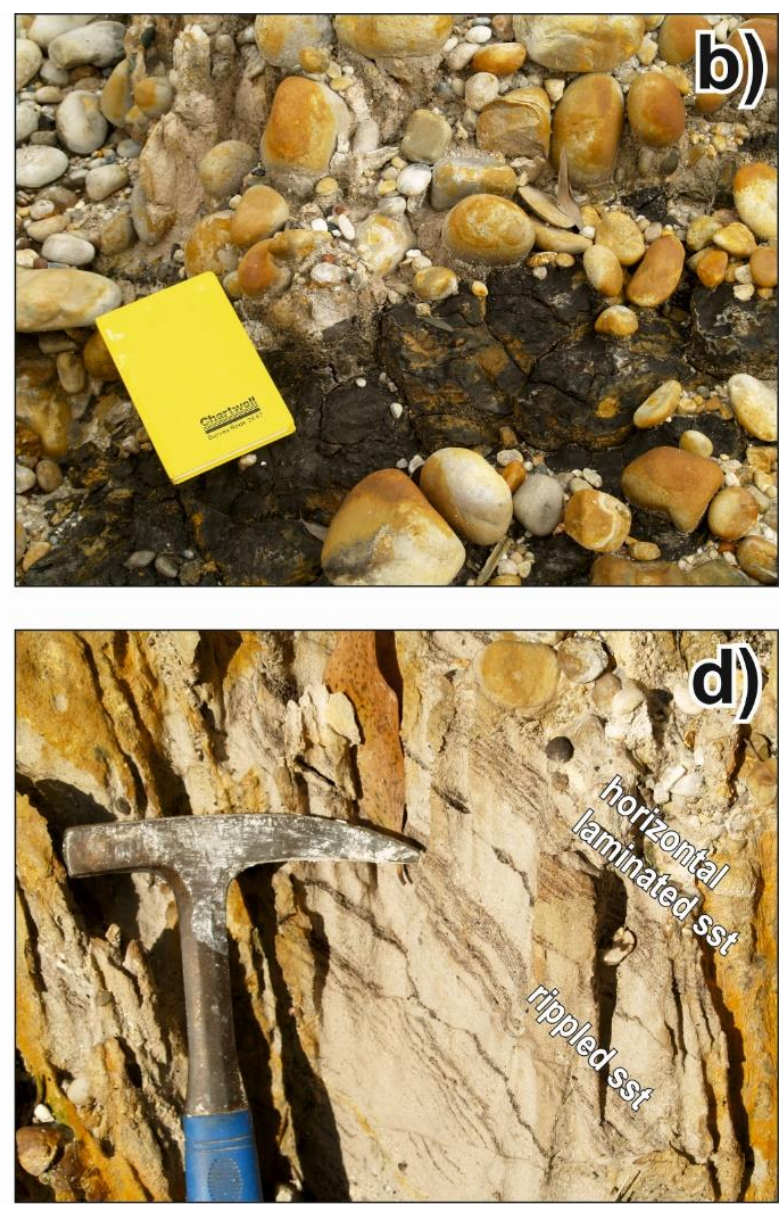

Figure 4: Field photographs of the Petra Jaya sediments (location WTB15). a) Petra Jaya sediments overlie with a basal conglomerate deeply weathered mudstone (possible Triassic turbidite). b) Cobbledsized well-rounded sandstone clasts that resemble the Kayan Sandstone. c) Crudely horizontal laminated sandstone with syn-depositional micro-faults overlies the basal conglomerate. d) Rippled and horizontal laminated sandstone, possible at the top of a channel. Carbonaceous material forms the top of ripples and the fine laminae. (cgl-conglomerate, sst-sandstone). 
Zircon U-Pb LA-ICP-MS analysis was performed at Birkbeck College, University of London with a New Wave NWR $193 \mathrm{~nm}$ laser ablation system coupled to an Agilent 7700 quadrupole-based plasma ICP MS with a two-cell sample chamber. A spot size of $25 \mu \mathrm{m}$ was used for the ablation. The Plešovice zircon (337.13 $\pm 0.37 \mathrm{Ma}$; Sláma et al., 2008) as age standard and a NIST 612 silicate glass bead (Pearce et al., 1997) were used to correct for instrumental mass bias and depth-dependent inter-element fractionation of $\mathrm{Pb}$, Th and $\mathrm{U}$. Data reduction was performed with GLITTER software (Griffin et al., 2008) and the data was corrected using the common lead correction method of Andersen (2002), which is used as a ${ }^{204} \mathrm{~Pb}$ common leadindependent procedure. The age obtained from the ${ }^{207} \mathrm{~Pb} /{ }^{206} \mathrm{~Pb}$ ratio is given for grains older than 1000 Ma. For ages younger than $1000 \mathrm{Ma}$, the ages obtained from the ${ }^{238} \mathrm{U} /{ }^{206} \mathrm{~Pb}$ ratio are given because ${ }^{207} \mathrm{~Pb}$ cannot be measured with sufficient precision (Nemchin and Cawood, 2005). Concordance was tested for all grains older $15 \mathrm{Ma}$ by using a $10 \%$ threshold between the respective $\mathrm{U}-\mathrm{Pb}$ ratios. For young ages a simple concordance test is insufficient as the concordance range is too small to test reliably. Instead, all analyses $<15 \mathrm{Ma}$ were considered concordant, except analyses which were interpreted to be affected by lead loss, inheritance or common $\mathrm{Pb}$ based on the TeraWasserburg diagram.

Age histograms and probability density plots were created using an R script that adopts the approach of Sircombe (2004) for calculating probability density. Isoplot 4.11 (Ludwig, 2003) was used for graphical illustration of the Tera-Wasserburg concordia diagram (Tera and Wasserburg, 1972) and weighted mean age calculations. Analytical results are presented in the Supplementary Table.

\section{RESULTS}

\section{Field Description}

\subsection{SEDIMENTS IN PETRA JAYA (NORTHERN KUCHING CITY)}

Tan (1993) discussed undated sediments in the northern part of Kuching city which he considered were an 'Older alluvium' of Quaternary age. These sediments are exposed along road cuts in Petra Jaya north of the Sungai Sarawak (Figure 2b), along the Batu Kawa Road in the western part of Kuching city, north of Kampung Poah in the eastern part of Kuching city, and in southern Kuching city near the airport (Haile, 1949; Tan, 1993). The 1:500,000 geological map of Heng (1992) does not display the young deposits, but they are marked on the geological map of Sarawak by Liechti et al. (1960) as Quaternary and shown on the detailed 1:25,000 geological map of the Kuching city area by Tan (1993). In this study these sediments were analysed from sequences at two locations in Petra Jaya; for simplicity they are called Petra Jaya sediments.

The first location (WTB14, WTB15) is along the road Jalan Bukit Siol (Figure $3 \mathrm{~b}$ ) and the second location (WTB16, WTB17) is along the Foreign Diplomatic Mission Road (J1. Diplomatik) south of Petra Jaya Hospital along the Sungai Santubong (Figure 3b). Typically, the succession includes gravel beds and conglomerates containing wellrounded clasts associated with pebbly sandstone layers. Conglomerate clasts range from fine gravel to cobble and are predominantly indurated sandstone clasts and quartz clasts. Tan (1993) also reported clasts of hornfels, chert, jasper, and igneous rocks, which have been observed at the second Petra Jaya location in this study. 

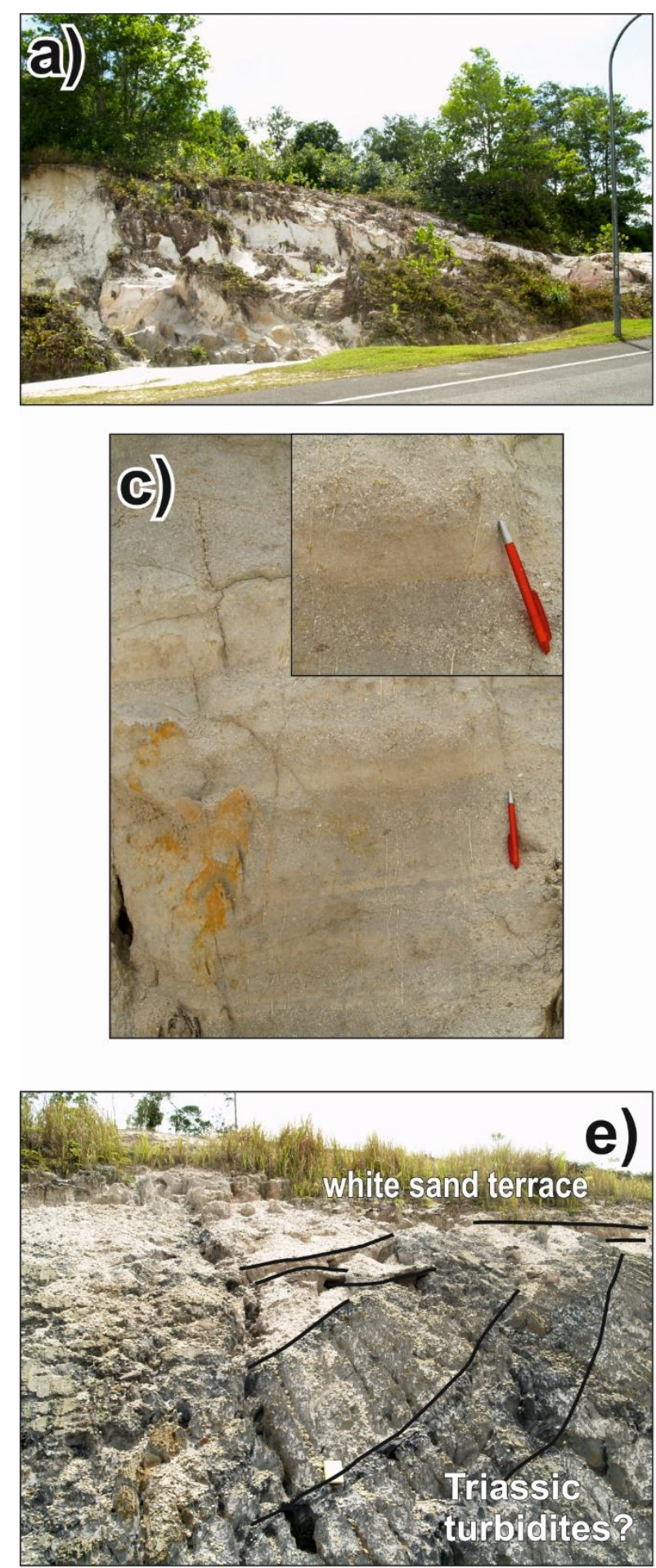
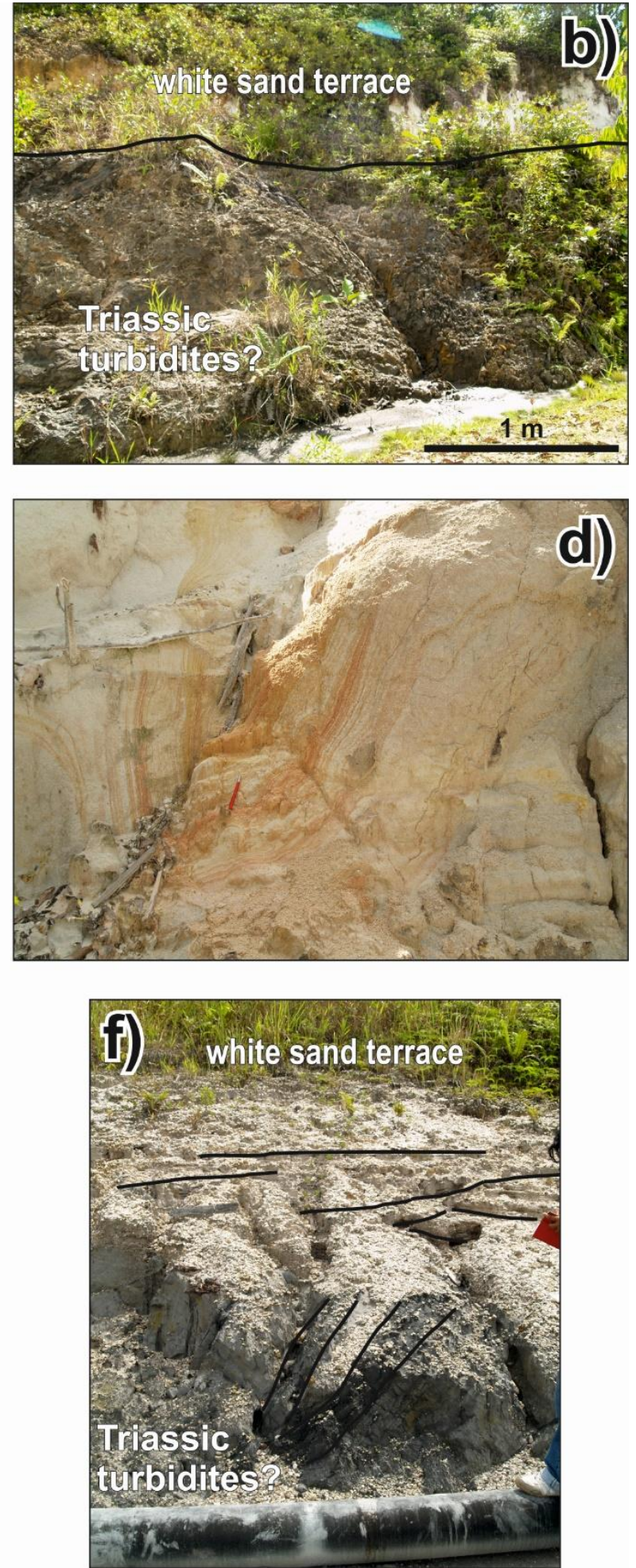

Figure 5: Field photographs of the Petra Jaya sediments (locations WTB14, WTB16 and WTB17). a) and b) White sand terrace unconformably on top of deeply weathered mudstone-siltstone (possible the Triassic turbidite) (WTB14) The white sandstone terrace is stratigraphically higher up as the section at WTB15. c) Alternation of white coloured pebbly sandstone layers and clayey fine sandstone that indicates multiple flooding events (WTB14). d) Liesegang weathering rings in the white sandstone (WTB14). e) and f) Steeply dipping dark mudstone-siltstone alternations (Triassic turbiditic 'Kuching' Formation) overlain unconformably by Petra Jaya conglomerates (WTB16 and 17).

The conglomerate matrix consists of a clayey sand to silt.
Horizontal laminated, rippled, and cross-bedded sandstone were also observed. Carbonaceous material forms fine laminae and the tops of ripple 
crests. Wood fragments are also common, and Tan (1993) reported incomplete tree trunks.

Location 1 includes two studied outcrops and shows an unsorted basal gravel bed (WTB15) of $c a$. 5 to $10 \mathrm{~cm}$ thickness in a sandy matrix unconformably on top of a deeply weathered black mudstone (Figure 4a). Clasts are of gravel to cobble size and are almost exclusively made up of indurated well-rounded sandstone (Figure 4b). Upsection horizontal laminated sandstone (Figure 4c) and rippled sandstone (Figure 4d), both up to 15 $\mathrm{cm}$ thickness, are interbedded with conglomerate layers up to $5 \mathrm{~cm}$ thickness and fine sandstone with interbedded pebbly sandstone layers. Micro faults in sandstone beds (Figure 4c) indicate soft sediment deformation probably reflecting high syndepositional water content. The top of the section (WTB14) is exposed south of the basal gravel bed exposure and records deposits stratigraphically about 2 to $4 \mathrm{~m}$ higher up. This section exposes potentially the same deeply weathered mudstone at the southern end of the road cut overlain by white sandstone (Figure $5 \mathrm{a}$ and $\mathrm{b}$ ), indicating a very irregular surface at the time of deposition into which a main channel with a basal conglomerate at WTB15 has cut deeply into the surrounding basement. Most of the outcrop consists of unsorted pebbly sandstone or coarse sandstone layers interbedded with clayey fine sandstone layers (Figure 5c). Layer thickness ranges between 5 and $25 \mathrm{~cm}$, with especially the pebbly sandstones tending to be thicker. The top of the section consists of a podsolised unsorted fine to mediumgrained leached white sandstone with grey mud clasts (Figure $5 \mathrm{a}$ and $\mathrm{b}$ ). The lower section shows Liesegang secondary weathering cross-cutting the bedding (Figure $5 \mathrm{~d}$ ).

Location 2 follows several road cuts along the Jl. Diplomatik between the Petra Jaya Hospital and the Bako road roundabout. The section displays horizontal beds of conglomerate up to $30 \mathrm{~cm}$ in thickness and sandstone up to $10 \mathrm{~cm}$ in thickness unconformably on top of weathered slumped siltstone-mudstone alternations (Figure $5 \mathrm{e}$ and f). Conglomerates are more polymict compared to location 1 and clasts include sandstone, quartz, chert, mudstone, hornfels and igneous rock fragments; clast size reaches only up to medium to coarse gravel (Figure 6a). Clasts are rounded to well-rounded. Conglomerates with channel structures indicate confined flow (Figure 6a). Sandstones are horizontal laminated (Figure 6b) and rippled, while trough crossbedding was also observed. Clayey fine sandstone and mediumgrained sandstone are common. Carbonaceous material and thin mud layers typically form the fine laminae and ripple tops. Lignite fragments are common in some conglomerate horizons (Figure $6 \mathrm{c}$ ). Very thin (up to $8 \mathrm{~cm}$ ) conglomerates as basal bed filling have also been observed in some places fining upwards into sandstone (Figure 6d).

Tan (1993) reported a maximum thickness of c. 5 $\mathrm{m}$ in Petra Jaya and Haile (1949) reported a thickness of 10 to $13 \mathrm{~m}$ from southern Kuching city. Based on the observed section in location 1 the thickness of the Petra Jaya deposits is at least $10 \mathrm{~m}$.

\subsection{WHITE SANDSTONE AT KAMPUNG JANGKAR}

The area around Kampung Jangkar (Figure 3c) is mapped as the Jurassic to Cretaceous deep marine Serabang Formation (Figure 1) based on river traverses (Liechti et al., 1960; Wolfenden and Haile, 1963; Heng, 1992). New road exposures in 2012 revealed that at least some of the area in the east close to the Batang Kayan is covered by yellowish quartz-rich sandstone, resembling the Kayan Sandstone (Breitfeld et al., 2018). 

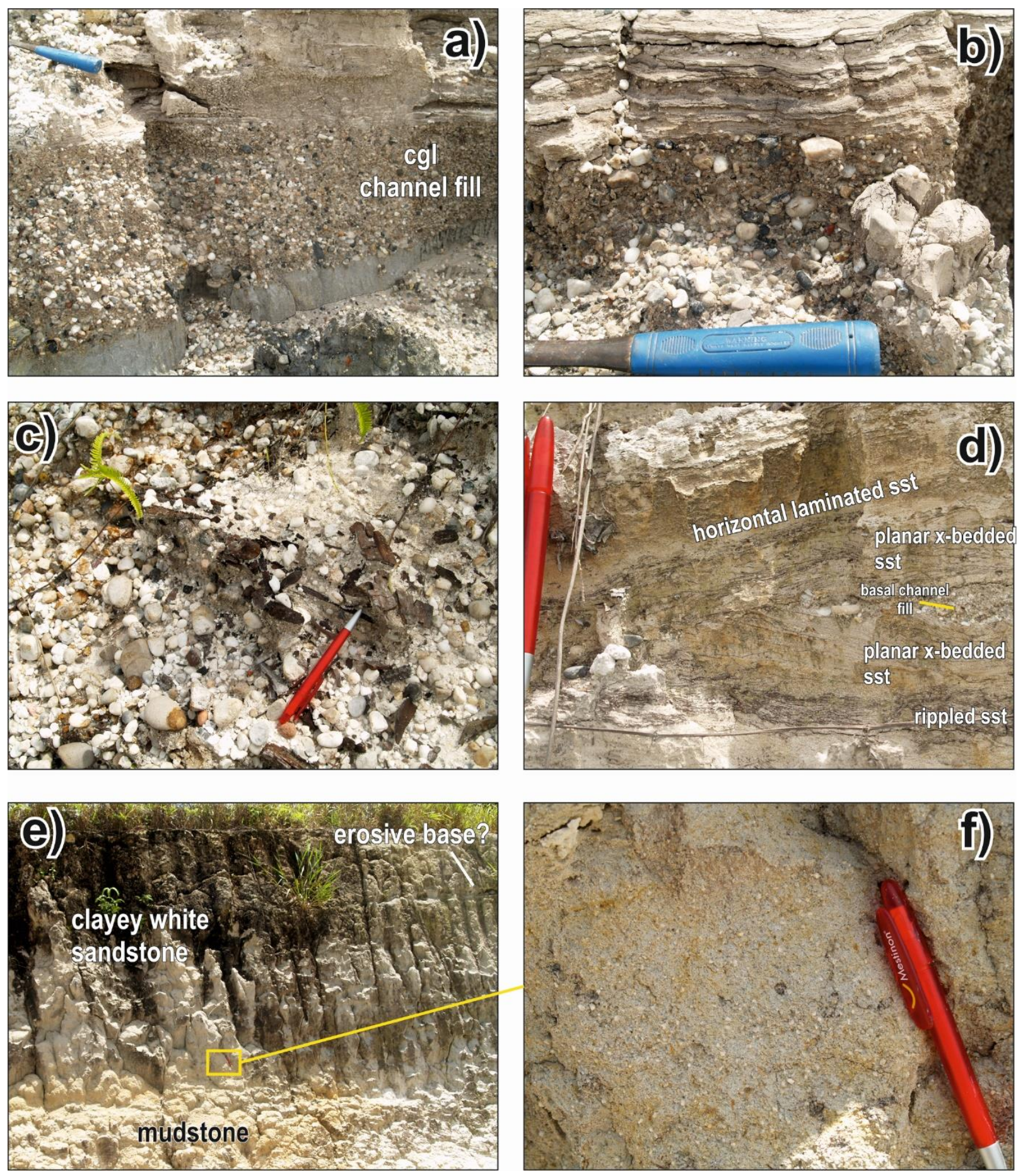

Figure 6: Field photograph of the Petra Jaya sediments (WTB17) and the Kampung Jangkar sediments (WTB72). a) Polymict conglomerate as channel fill (WTB17). Clasts consist of quartz, sandstone, mudstone, chert, igneous fragments and lignite. b) Horizontal laminated siltstone overlies a conglomerate bed, indicating decrease of energy during the deposition of the sequence (WTB17). c) Rounded quartz and sandstone clasts and abundant lignite fragments in the conglomerate. d) Small sandstone channel beds (WTB17). The first channel consists of rippled and planar cross-bedded sandstone, which is truncated by a second channel. The second channel has a basal conglomerate channel fill overlain by rippled sandstone. e) Kampung Jangkar white sandstone on top of yellowish clay or mudstone (WTB72). Possible some channel-features (e.g., erosive base) are visible. f) Close-up of the white sandstone showing angular quartz grains and rounded mudstone clasts in a clayey matrix. 
Around Kampung Jangkar new road exposures also excavated a very white, loosely consolidated, sandstone unit (WTB72). The deposits are not marked on the 1:500,000 geological map of Heng (1992), and the detailed 1:50,000 map of Wolfenden and Haile (1963) shows only some possible Pleistocene riverine deposits c. $3.5 \mathrm{~km}$ north of the studied location. The geological map of Liechti et al. (1960) displays the Kampung Jangkar sandstones and those further north as Quaternary (Figure 2).

At Kampung Jangkar is a deeply weathered section of weathered yellowish mudstone which is overlain by an unsorted white to yellowish medium to coarse grained quartz-rich sandstone (Figure 6e). There are angular to sub-angular quartz grains in a very fine-grained white matrix with frequent fragments of carbonaceous material including lenses of lignite and fossil wood fragments (Figure 6f). The deposits are only loosely consolidated. The white colour is probably the result of extreme podsolization. The succession is horizontally bedded, but as a result of deep weathering no primary sedimentary structures could be confidently identified, although relicts of erosive bases and channel structures may be present. Based on a change in strike and dip, the sequence is interpreted to be unconformable on deep marine sediments of Jurassic Serabang Formation, but the contact was not observed.

\section{Petrography}

The three analysed samples are all quartz-rich with only few lithic fragments. Depending on the amount of clay/mud matrix they are classed as quartz arenite or quartz wacke in the Pettijohn et al. (1987) scheme. The Kampung Jangkar sample TB72 is a quartz wacke consisting of monocrystalline angular to sub-angular quartz grains in a clay matrix (Figure 7a). The Petra Jaya sediments (TB14 and TB15b) show a wider range of framework grains, including monocrystalline and polycrystalline quartz (Figure $7 \mathrm{~b}$ ), chert, and mainly sedimentary lithic fragments. Quartz grains are sub-rounded to sub-angular. The absence or extremely low abundance of feldspar in all analysed samples is notable, which is likely a result of advanced tropical weathering and complete breakdown of feldspars (Suttner et al., 1981; Johnsson et al., 1988; Smyth et al., 2008).

\section{Detrital Zircon U-Pb Geochronology}

\subsection{SAMPLE TB15b - PETRA JAYA SANDSTONE}

For sample TB15b 98 zircon grains were analysed for $\mathrm{U}-\mathrm{Pb}$ geochronology and 98 concordant analyses were acquired. The grains show mostly concentric oscillatory or simple zoning with grain shapes ranging from angular euhedral to well rounded (Figure 8). There are 86 Phanerozoic and 12 Precambrian ages (Figure 8). The youngest age population with 25 zircons is Middle Miocene to Pliocene, and ranges from c. 4.8 to $14 \mathrm{Ma}$. These grains are mostly oscillatory zoned with euhedral shapes; some are very elongated with a high length to width ratio (Figure 8). The youngest ages cover a range from c. 5 to $8 \mathrm{Ma}$. Grain G004 has a $6.6 \pm$ $0.5 \mathrm{Ma}$ dark core with a $4.9 \pm 0.5 \mathrm{Ma}$ rim in cathodoluminescence (CL) (Figure 8). The weighted mean of the youngest population comprising ten grains is $5.1 \pm 0.2 \mathrm{Ma}$ (MSWD=0.3), and a slightly older population consisting of eight grains has a weighted mean age of $6.8 \pm 0.4 \mathrm{Ma}(\mathrm{MSWD}=2)$ (Figure 8).

The major age population of 47 zircons is Cretaceous with an Early Cretaceous peak and there is a single Paleocene grain (Figure 8). Older ages include a scatter of Early Jurassic, Triassic and Permian grains with a single Devonian age. 

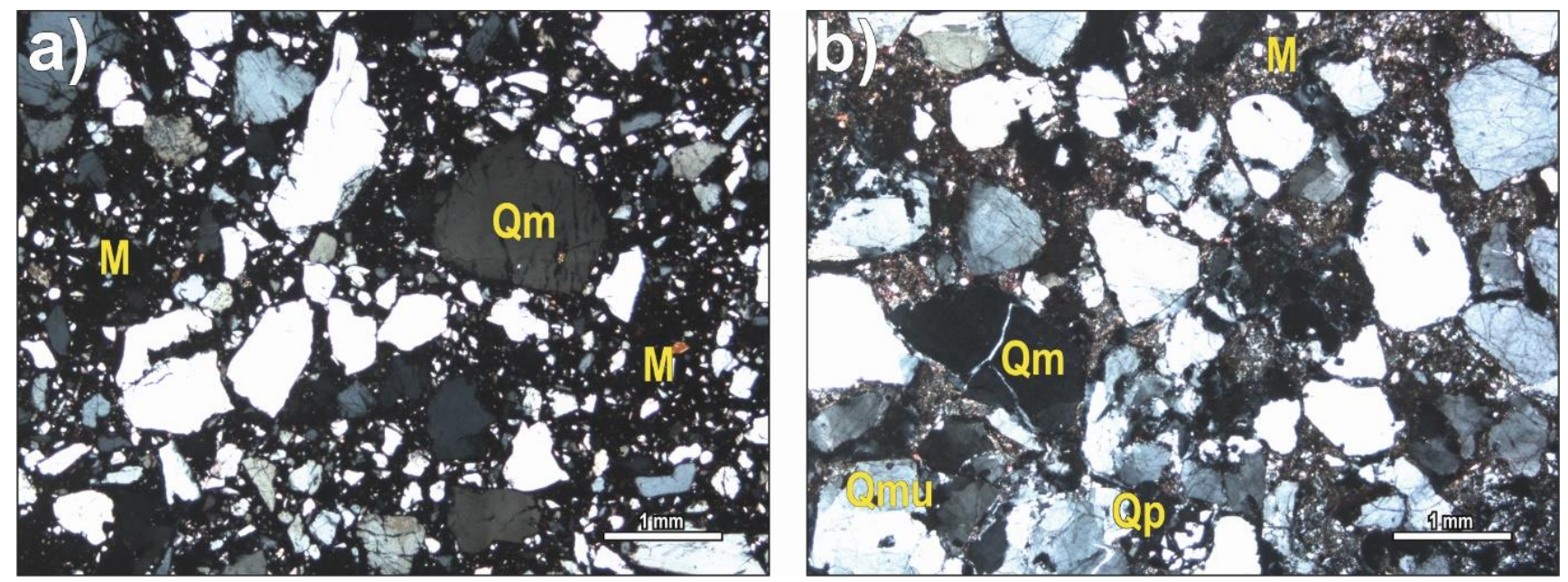

Figure 7: Cross polarized photomicrographs of samples a) quartz wacke TB72 (Kampung Jangkar) and b) quartz wacke TB14 (Petra Jaya). TB72 consists of angular to sub-angular monocrystalline quartz grains in a clayey matrix (black). TB14 consists predominantly of monocrystalline quartz including undulous varieties in a mud matrix. Some polycrystalline quartz is also present. In contrast to TB72, the Petra Jaya sample shows a wide range of quartz grain shapes from angular to rounded. (Qm - monocrystalline quartz, Qp - polycrystalline quartz, Qmu - undulatory monocrystalline quartz, $M-$ matrix).

The Precambrian is represented by scattered ages around $580 \mathrm{Ma}$, c. 880 to $1100 \mathrm{Ma}$, c. $1.86 \mathrm{Ga}$, and between 2.42 to $2.55 \mathrm{Ga}$, mostly from well-rounded grains.

\subsection{SAMPLE TB72 - WHITE SANDSTONE AT}

\section{KAMPUNG JANGKAR}

In total 49 zircon grains were analysed with 47 concordant ages. Most zircons $(n=43)$ are Cretaceous with ages between 77 and $86 \mathrm{Ma}$ (Figure 9) and a weighted mean age of $79.9 \pm 0.6$ Ma $(M S W D=2.3)$. There are three older zircons which are Early Cretaceous, Late Jurassic and Early Jurassic (Figure 9). All grains are angular and have a euhedral shape with oscillatory or simple zoning in CL (Figure 9). The youngest age is from a grain dated as $4.2 \pm 0.2 \mathrm{Ma}$ (Figure 9) which shows oscillatory zoning and is relatively dark in CL. However, the grain does not appear different to many of the Late Cretaceous zircons. In contrast to sample TB15b, there are no Palaeozoic or Precambrian zircons.

\section{DISCUSSION}

\section{Environment of Deposition and Age of The Sediments}

The successions in Petra Jaya are interpreted as braided river deposits in which the well-rounded basal conglomerate represents a coarse channel fill or bedload in a very high energy environment with high rates of clastic input. Clast-supported conglomerates indicate bedload deposition from stream flows (Reading, 1996). Gravel conglomerates can also be interpreted as bar and lag deposits (Miall, 1985; Labourdette and Jones, 2007). Trough cross-bedded beds that truncate older channels indicate stacked channels, high sedimentation rates and channel migration.

Rippled or horizontal laminated sandstones were deposited at the top of channels when energy levels decreased. Fine laminated sandstones are probably overbank or floodplain deposits (Miall, 1985). Pebbly sandstones represent either sheet floods or channel fills (Miall, 1985). Carbonaceous material suggests vegetated floodplains. 


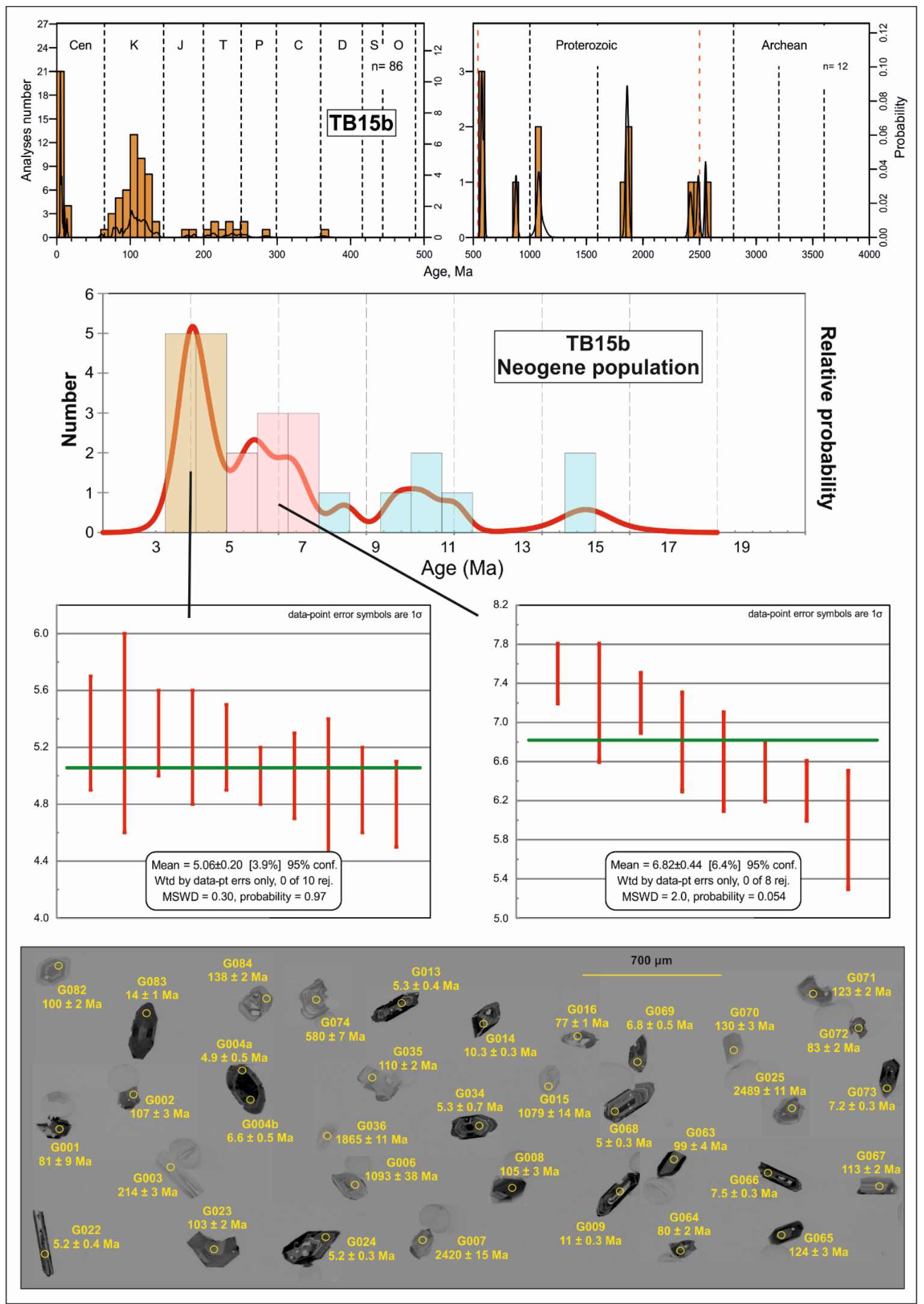

Figure 8: Detrital zircon age diagrams for sample TB15b (Petra Jaya sediments), displaying the two main populations in the Neogene and in the Cretaceous. Zoomed section shows the age distribution in the Neogene with weighted mean age calculations for the two youngest populations. CL images of assorted zircon grains display the whole range of ages and associated zircon character. 
Although not certain because of the deeply weathered character of the underlying mudstone, exposures along the Sungai Santubong reveal a steeply dipping, slumped mud-siltstone alternation resembling the early Mesozoic turbiditic deposits reported by Breitfeld et al. (2017) also from northern Kuching. Tan (1993) assigned these deposits to the undated Tuang Formation. However, Tate (1991) and Tate and Hong (1991) had previously used the term Tuang Formation for undated metamorphic rocks interpreted to be Carboniferous or older.

Breitfeld et al. (2017) dated the metamorphic rocks as Triassic and suggested that the terms Tuang Formation and Kerait Schist should be abandoned and the metamorphic rocks should be renamed the West Sarawak Metamorphics, with exposures mainly to the south and east of Kuching (Breitfeld et al., 2017). The turbidites in Petra Jaya are part of the Triassic Kuching Formation of Breitfeld et al. (2017) and are the deeper marine equivalent of the widely distributed shallow marine Sadong Formation. These deposits are clearly unconformably overlain by the Petra Jaya sediments with a very prominent angular unconformity.

The deposits at Kampung Jangkar do not yield any clear primary sedimentary structures because of their deeply weathered state. The pebbly sandstone does not show any confinement and it is therefore concluded that a sheet-flood deposition is the most likely. Those are probably related to deposition of hyper-concentrated, fluidal and plastic stream flows in a braided fluvial system (Martin and Turner, 1998) or are a product of amalgamation of complex, multi-storey sandstone beds (Williams and Hillier, 2004). A relict erosive base and possible channel structure in a single bed suggest a channel fill deposit. The underlying mudstone is interpreted as an overbank facies, swamp or soil (Miall, 1985; McCabe, 1987), indicating quieter periods or no sedimentation. Based on the geological map, the

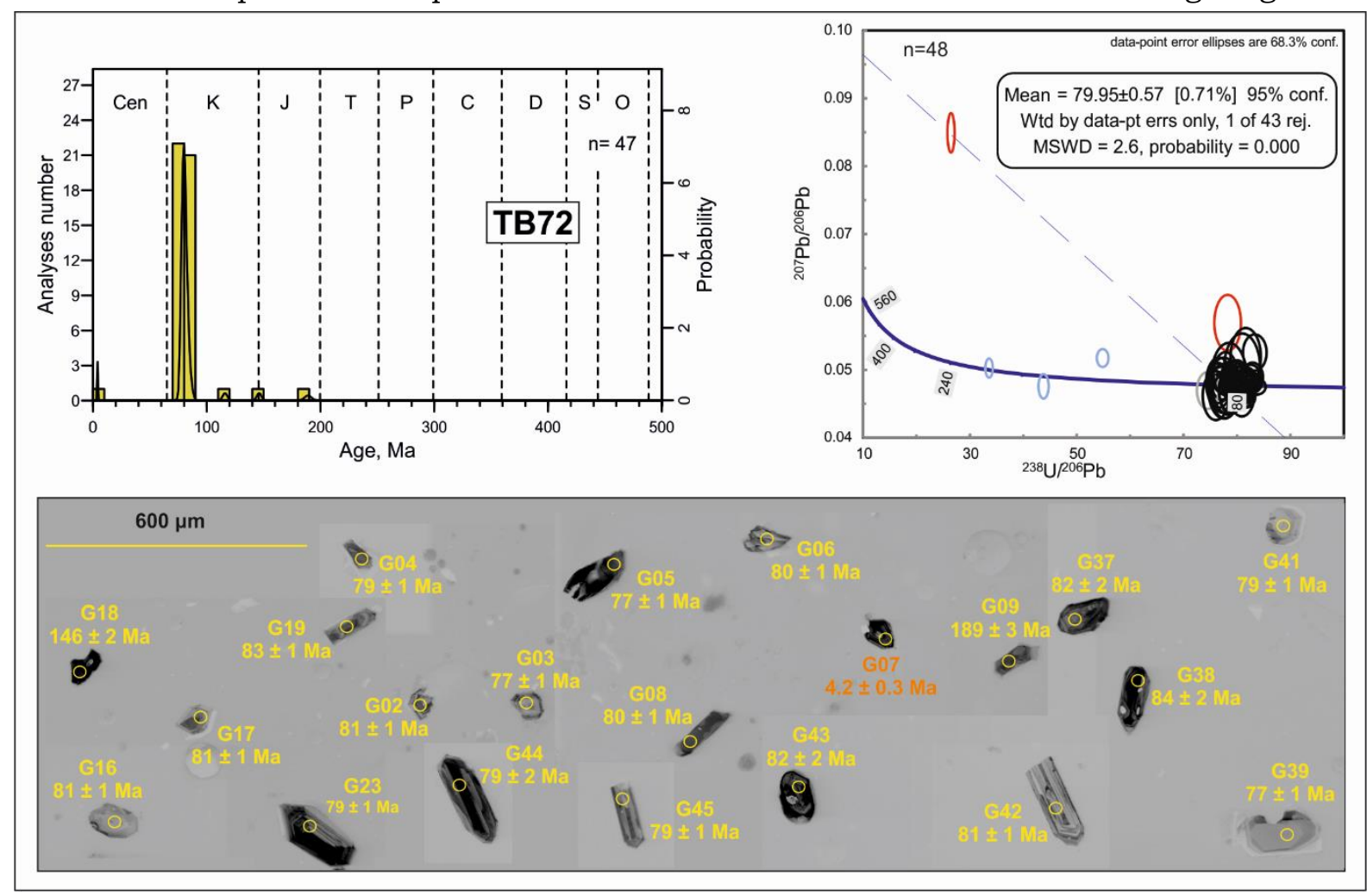

Figure 9: Detrital zircon age diagrams for sample TB72 (Kampung Jangkar sediments), displaying the whole range of zircons as histogram with probability density curve and weighted mean age calculation for the upper Cretaceous main population. CL images of assorted zircon grains are displayed, showing mostly angular concentric zoned zircons including the Pliocene grain. 
Kampung Jangkar sediments likely rest unconformably on Jurassic turbidites (Serabang or Pedawan Formations).

The white colour observed in both sections is a product of leaching and podsolization and not a primary feature. It is not known if the two analysed sections are correlative. They could be contemporaneous, but age relations cannot be resolved with the data available. Thorp et al. (1990) also concluded that white sand terraces in NW Kalimantan are a characteristic bleached podzol horizon feature and do not represent a single sedimentary unit; therefore, a correlation of white sand terraces across Borneo is not applicable. However, they clearly have different sources as discussed further below.

Tan (1993) concluded that the 'Older alluvium' in northern Kuching, which in places lies about 10 to $15 \mathrm{~m}$ above local sea level probably results from eustatic sea-level changes. The succession at Kampong Jangkar was previously not documented in detail. Wolfenden and Haile (1963) discussed an older terrace alluvium from Tanjung Serabang and between the Pueh and Gading intrusions several kilometres north of the sample location, which resembles the observed section, and concluded a probable Pleistocene age. These sediments were interpreted as being older than the Quaternary alluvium which includes recent river, delta, estuarine or marine deposits (Wolfenden and Haile, 1963; Tan, 1993).

The analysed sections in this study at Petra Jaya are slightly more elevated than reported previously at c. 15 to $27 \mathrm{~m}$ above sea level. The section at Kampung Jangkar is c. $32 \mathrm{~m}$ above sea level and even higher. Sedimentation in response to eustatic sea level changes seems to be the most likely explanation, but tectonic and certainly climate interaction might have had an influence. Although the age of the analysed successions cannot be determined with certainty, a Pleistocene age is probable. Wilford (1967) and Thorp et al. (1990) suggested a Pleistocene age range for possible correlative successions in Sarawak and in NW Kalimantan. Thorp et al. (1990) and Thorp and Thomas (1992) reported latest Pleistocene to Holocene radiocarbon ages from white sand terraces in NW Kalimantan and Wilford (1967) reported c. $700 \mathrm{ka}$ old tektites in one terrace. However, the abundance of Pliocene zircons in the analysed Petra Jaya sample also could indicate deposition soon after a large Pliocene magmatic event and a Pliocene age cannot be ruled out.

\section{Provenance of The Pleistocene Sediments}

\subsection{CONGLOMERATE IN NORTHERN} KUCHING CITY (Jl. Bk. Siol) - TB15b

In sample TB15b the detrital zircons have essentially two main age peaks, suggesting two major sources. The youngest peak of Late Miocene to Pliocene age (Figure 8) indicates a substantial contribution from young igneous rocks. The second major population covers the whole Cretaceous with a main peak between c. 100 and 130 Ma (Figure 8).

These zircons were originally derived from the igneous and metamorphic rocks of the Schwaner Mountains including the Sepauk Tonalite and Pinoh Metamorphic Group (Hennig et al., 2017; Breitfeld et al., 2020b), but have since been recycled into various Cretaceous and Cenozoic sedimentary formations of the Kuching Zone (Breitfeld et al., 2017; Breitfeld and Hall, 2018) and other parts of Borneo (e.g. Witts et al., 2012; van Hattum et al., 2013; Galin et al., 2017; HennigBreitfeld et al., 2019). There are few older zircons in the analysed sample, another feature of Schwaner origin rocks (Breitfeld et al., 2020). Those present include Early Jurassic, Permian- 
Triassic and scattered Precambrian (c. $550 \mathrm{Ma}, 1.1$ $\mathrm{Ga}, 1.85 \mathrm{Ga}, 2.5 \mathrm{Ga})$ ages.

As the underlying Triassic Kuching Formation is dominated by Permian-Triassic and Paleoproterozoic zircons (Breitfeld et al., 2017), it can be concluded that this formation was not recycled into the Petra Jaya sediments.

Breitfeld and Hall (2018) described detailed local variations in the detrital provenance signature from the mostly Paleogene Kayan and Ketungau Groups (Figure 10). Most of these sediments are dominated by Cretaceous zircons but include prominent Permian-Triassic and Precambrian age components (Breitfeld and Hall, 2018). The Cretaceous Pedawan Formation follows the same trend (Breitfeld et al., 2017). As discussed above the well-rounded sandstone cobbles within the basal conglomerate closely resemble the Paleocene Kayan Sandstone of the Bungo Range. The detrital zircon age populations of the Bungo Range sandstones (Figure 10) are dominated by Cretaceous zircons with few older grains (Breitfeld and Hall, 2018). This variety of the Kayan Sandstone is also present at Gunung Serapi and at Tanjung Serabang. Based on this it is concluded that erosion and recycling of Bungo Range-type Kayan Sandstone from the south was the source. The younger Early Eocene Penrissen Sandstone that is unconformably on top of the Bungo Range Kayan Sandstone, also to the south, the slightly older Kayan Sandstone exposed at the Kayan Syncline and Tanjung Santubong, and the whole Eocene Ketungau Group (Bako-Mintu Sandstone, Ngili Sandstone, Silantek Formation, Tutoop Sandstone) were not sources for the Petra Jaya sediments (Figure 10).

There are no Early Miocene zircons that indicate a contribution from the widely distributed West Sarawak and NW Kalimantan Sintang Suite igneous rocks (Figures 11 and 12) (Williams and
Harahap, 1987; Breitfeld et al., 2019). However, there are a few zircons ranging from 10 to $14 \mathrm{Ma}$ with similar ages to the Bau Suite igneous rocks (Breitfeld et al., 2019) which are restricted to the region of Bau and southern Kuching city (Figure 11).

It is therefore concluded that the source area of the Petra Jaya sediments was immediately to the south between the now prominently exposed Bungo Range and the town of Bau. No Pliocene igneous rocks are known from the area but the abundance of Pliocene detrital zircons suggests a significant contribution from such a source. This could indicate that the conglomerate is as old as Pliocene and zircons were derived from a contemporaneous volcanic eruption. Alternatively, the conglomerate is Quaternary, and the Pliocene source has now been completely removed by erosion.

\subsection{WHITE SANDSTONE AT KAMPUNG JANGKAR - TB72}

Sample TB72 was sourced almost exclusively from a single igneous source, indicated by the very narrow weighted mean age based on the majority of detrital zircons (Figure 9).

The weighted mean age of $79.9 \pm 0.6 \mathrm{Ma}$ (Figure 9) is almost identical to zircon U-Pb ages presented by Hennig et al. (2017) for the Pueh and Gading plutons of $78.6 \pm 0.3$ and $79.7 \pm 1.0 \mathrm{Ma}$ respectively. The few Early Cretaceous and Jurassic ages are likely inherited zircons of the Pueh pluton (Hennig et al., 2017). The single Pliocene zircon could be excluded from consideration, perhaps reflecting alteration, but since sample TB15b has abundant similar young zircon ages, it is concluded that the age is significant and must have been derived from nearby acid igneous source rocks, although it is not clear how it was transported into the Jangkar deposit. 

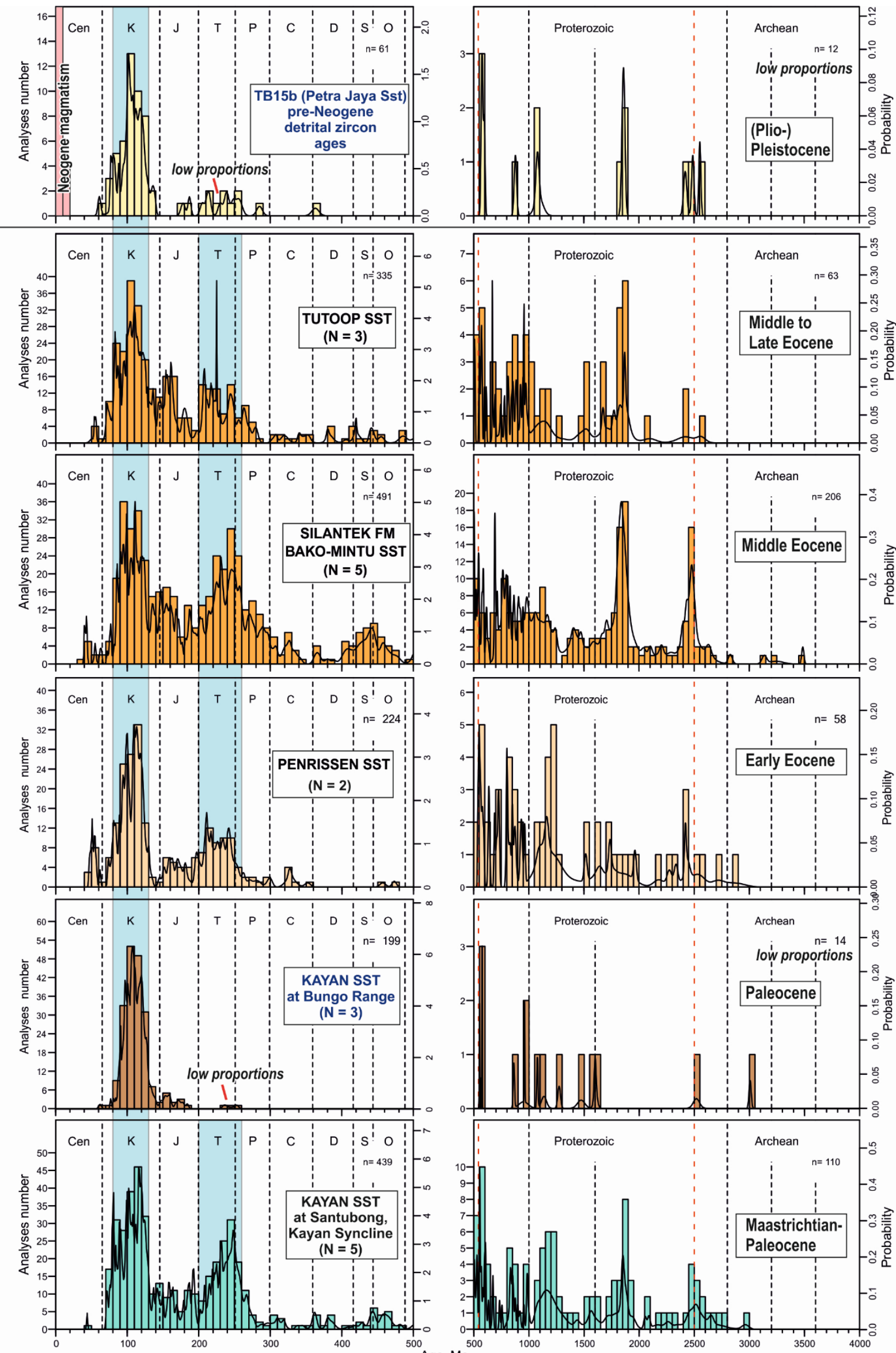

Figure 10: Comparison of detrital zircon age populations from Cenozoic sandstones from West Sarawak (data from Breitfeld and Hall, 2018) with sample TB15b of the Petra Jaya sediments, displaying the similarities with the Bungo Range Kayan Sandstone, and the differences to all other formations (absence of pre-Cretaceous zircons). Only detrital zircons older than the Miocene are displayed for $T B 15 b$ for comparison. 
Unlike sample TB15b and all detrital zircons presented by Breitfeld and Hall (2018) for the fluvial-deltaic sediments of the Maastrichtian to Late Eocene Kayan and Ketungau Groups of West Sarawak, where the Cretaceous is dominated by Lower Cretaceous zircons (Figure 10) derived from the Schwaner Mountains, TB72 has almost none of these ages and is dominated by much younger Cretaceous zircons. It is therefore concluded that the Pueh pluton was likely the single source for the Jangkar white sandstone with potentially very minor input of recycled material from underlying sediments. The Gading pluton to the north of the sample location was probably supplying material to the north and not to the south based on its paleogeography. The weighted mean age from the Jangkar white sandstone can therefore also be used as the age of the Pueh pluton, adding another age to the dating of Hennig et al. (2017).

Since these Maastrichtian ages are rare in all Paleocene to Early Miocene samples reported so far from northern Borneo (e.g., Kayan, Ketungau, and Rajang groups, Nyalau Formation, Balingian Formation), including TB15b, it can be concluded that uplift and exposure of the Pueh and Gading plutons likely occurred relatively recently, but definitely after the Eocene with a restricted drainage.

\subsection{RIVER RECONSTRUCTION}

Both analysed sections are close to present-day rivers (Figure 11) and it is therefore highly likely that a similar drainage pattern was present at the time of deposition. However, there are some very important differences. At present the Sungai Jangkar drains the area of Kampung Jangkar north of the analysed section. The present-day river is a small tributary to the larger Sungai Stamin and is mostly mud-dominated similar to other presentday rivers in Borneo. The analysed section at TB72 is about $5 \mathrm{~km}$ east of the exposed Pueh intrusion and indicates a large alluvial sheet flood event with high input of clastic material, possibly associated with some channelised flow, different from the present-day. It is possible that these deposits represent the main drainage from the Pueh intrusion as part of an alluvial fan or larger river into the South China Sea (Figure11).

The deposits at Petra Jaya are between the presentday Sungai Sarawak and Sungai Santubong (Figure 3a). At present-day the Sungai Sarawak is the main drainage system of central West Sarawak, with headwaters back to the Bungo Range and to the area of Bau (Figure 3a and 11). Although the drainage system may have not changed significantly, both present-day rivers (Sungai Santubong, Sungai Sarawak) are mud-dominated and far from sedimentary rocks of the Kayan Sandstone. To produce the cobble conglomerate and the frequent gravel conglomerates very high energy must have been required and a closer proximity to the source is likely. Additionally, a large amount of sedimentary rock must have been removed to produce the Petra Jaya deposits. It is therefore concluded that deposits of the Kayan Sandstone similar to the present-day Bungo Range covered areas between the town of Bau and southern Kuching closer to the analysed section (Figure 11). The northern part of Kuching may represent a large, braided river system close to the sediment source, and the few outcrops observed are the last remains of a (Plio-) Pleistocene river system that covered much of the present-day Kuching city area. As the river system clearly drained an area where Bau Suite igneous rocks were exposed as indicated by the zircons, it can be assumed that alluvial gold is present since the Bau Suite is associated with gold mineralisation (Wofenden, 1965; Percival et al., 1990; Schuh and Guilbert, 1990). 


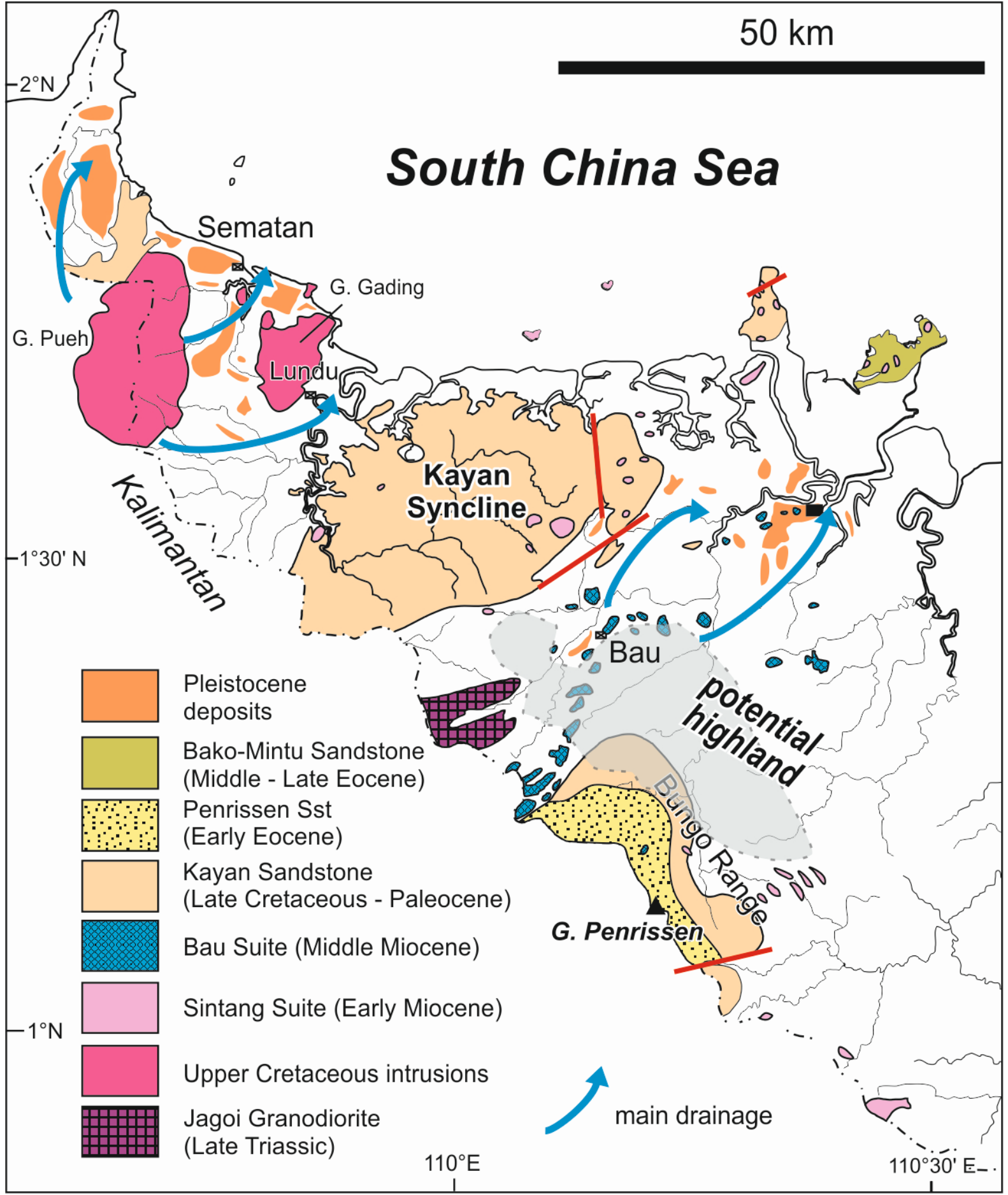

Figure 11: Inferred paleo-drainage and distribution of (Plio-) Pleistocene sediments in western West Sarawak (based on Liechti et al., 1960; Wolfenden and Haile, 1963; Tan, 1993), indicating two major source areas: 1) the Gading and Pueh batholiths with various major river system draining into the South China Sea, and 2) a now eroded potential highland in the Bau area with a large, braided river system in the region of Kuching city. Note that the sediments do not need to be contemporaneous and could be deposited at different times throughout the Pliocene and Pleistocene.

Both sections indicate that during the time of deposition in the Pleistocene higher bedrock erosion rates due to a different climate resulted in higher sedimentation rates compared to the present-day. Wurster et al. (2019) suggested savanna climate conditions in the late Pleistocene in Borneo with open vegetation, which would support higher erosion rates due to incomplete vegetation cover. The sediments are therefore not analogues of deposits of the present-day river systems in Borneo. In eastern West Sarawak along the Klingkang Range towards the Lupar Valley no 
similar Pleistocene sediments are reported (e.g., Liechti et al., 1960), which means they were either all completely removed or that there were no major rivers in the eastern part. It is also very likely that from the Pliocene onwards several changes in the drainage may have occurred. Figure 2 displays several rivers from e.g., Gunung Nuit and Gunung Sekadau that initially flowed towards the north and were captured later by the E-W flowing Sungai Sambas. In West Sarawak south of Lundu within the Kayan Syncline and in the Bau region there are also E-W flowing river sections that could have been connected to the Sungai Sambas at one point in time, before the drainage area of the Sungai Sambas began to shrink again and N-S flowing river systems in West Sarawak were established. More research on the Pleistocene deposits along the Sungai Sambas are needed to analyse the change in drainage in NW Kalimantan.

\section{Neogene Magmatism and Source of The Young Zircons}

The Niut Volcanics immediately south of West Sarawak (Figure 12) yielded K-Ar whole rock ages of 4.4 to $4.9 \mathrm{Ma}$ (Harahap, 1987; Bladon et al. 1989). The Metulang Volcanics to the east (Figure 12) may record at least two phases of magmatism. A younger phase is dated by K-Ar whole-rock as 1.7 to $2.4 \mathrm{Ma}$, and an older phase is dated by $\mathrm{K}-\mathrm{Ar}$ biotite and hornblende as c. $4.9 \pm 0.3$ to $8.2 \pm 0.1$ Ma (Bladon et al., 1989). Within the Sibu Zone are the Usun Apau Volcanics dated by Ar-Ar (biotite, plagioclase) as c. 3.9 to $4.1 \mathrm{Ma}$ associated with basaltic dykes at c. 2.1 Ma and the Linau Balui basalts of similar age (Figure 12) (Cullen et al., 2013). These Late Miocene to Pleistocene magmatic phases in Borneo are all dominated by basic volcanism that is unlikely to yield significant zircons. There is also no indication that basic material was reworked into the young sediments. The Nieuwenhuis Mountains in central Borneo form the largest area of similar basaltic volcanic rocks (Figure 12) but no age data are available, although volcanic features indicate very young ages. The only known acidic intrusion of young Neogene age in north Borneo is the Kinabalu granite at c. 7 to $8 \mathrm{Ma}$ (Cottam et al., 2010, 2013) in Sabah (Figure 12). Any connection or contribution is improbable because of the large distance to the Kuching Zone.

Neogene acid magmatism was recorded in NW Kalimantan and in West Sarawak from the Sintang Suite (Figure 12) (Williams and Harahap, 1987; Prouteau et al., 2001) dated by zircon U-Pb of c. 18.6 to 21.1 Ma (Breitfeld et al., 2019). Similar age volcanic rocks that also include basic compositions have been reported in East Kalimantan (Figure 12) with zircon $\mathrm{U}-\mathrm{Pb}$ ages of c. 19 to $20 \mathrm{Ma}$ (Setiabudi et al., 2007; Davies et al., 2008). A tuff layer of 19.6 $\pm 0.1 \mathrm{Ma}$ has been reported by Burley et al. (2021) from the island of Labuan and may be related to the Sintang Suite magmatism. A younger Middle Miocene phase in West Sarawak named the Bau Suite based on their occurrence around the town Bau (Figure 11a, b and 12) was dated by Breitfeld et al. (2019) with zircon U-Pb as c. 12 to $14 \mathrm{Ma}$. Prouteau et al. (2001) presented whole-rock K-Ar ages that were as young as c. $6.4 \mathrm{Ma}$, but may be affected by later stage alteration (Breitfeld et al., 2019). Both Bau Suite samples of Breitfeld et al. (2019) have one altered zircon with an age of c. 5 Ma which may be a result of lead-loss associated with possible Pliocene hydrothermal alteration.

Neither of the here studied samples records any Sintang Suite age zircons, indicating they were not a source or not exposed during deposition. TB15b has a wide range of Middle Miocene to early Late Miocene zircons with ages of c. 10 to $14 \mathrm{Ma}$, which resemble the ages of the Bau Suite of Breitfeld et al. (2019). Both weighted mean ages from the Upper Miocene to Pliocene populations of TB15b 


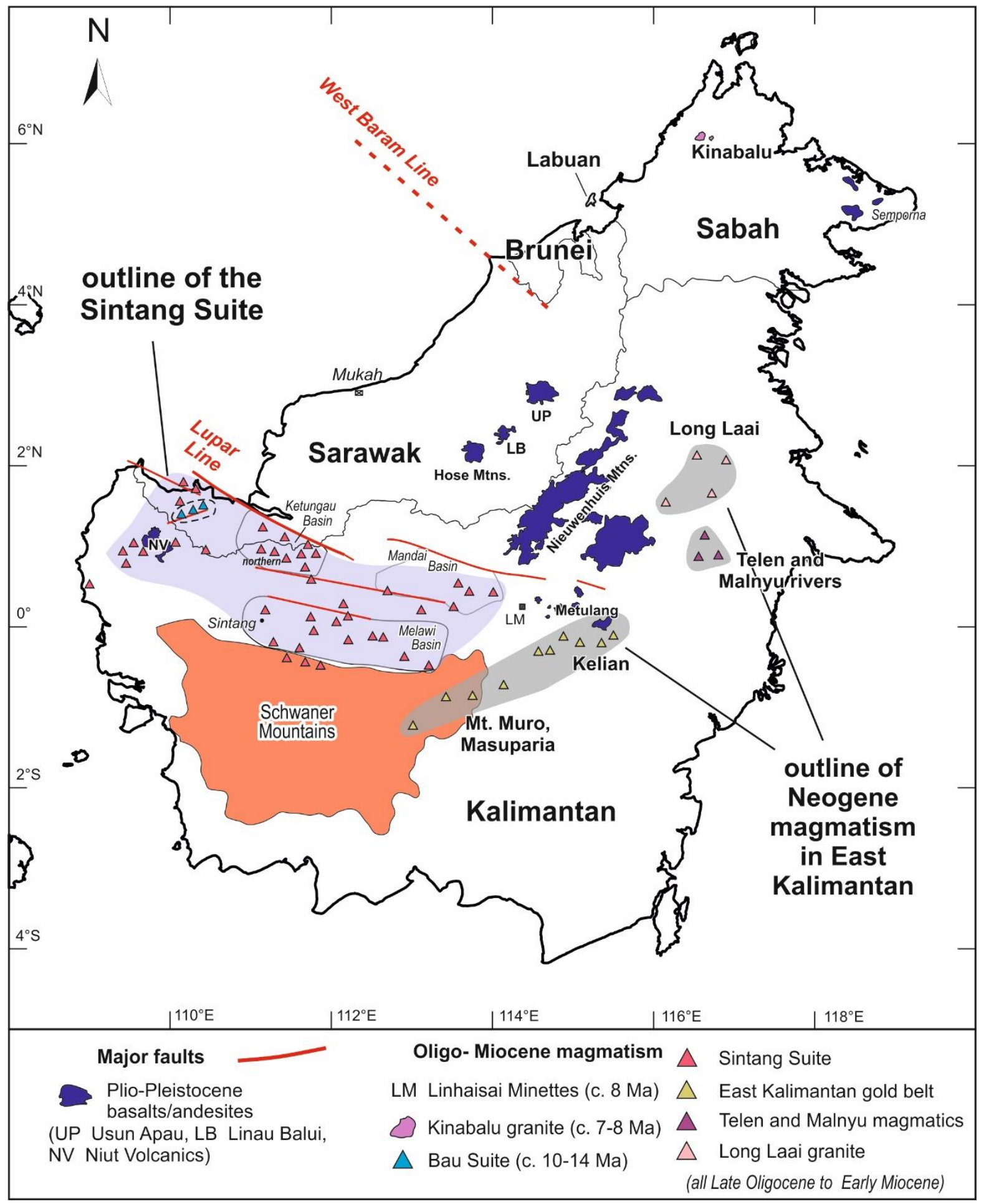

Figure 12: Distribution of Cenozoic magmatism in Borneo as reference for possible sources for the Pliocene and Late Miocene detrital zircons observed (modified from Breitfeld et al., 2019). The widespread Plio-Pleistocene volcanic rocks are predominantly basic and not sources but show the extent of this magmatic phase.

with ages of $5.1 \pm 0.2 \mathrm{Ma}$ and $6.8 \pm 0.4$ Ma resemble the earlier phase of the Metulang Volcanics and the Niut Volcanics phase (Harahap, 1987; Bladon et al., 1989). But an even closer resemblance is with the altered c. $5 \mathrm{Ma}$ zircons of the Bau Suite samples, which also would explain the Bau Suite age Middle to Upper Miocene zircons in TB15b, if the Bau region were the source as discussed earlier. The youngest zircon of TB72 with an age of $4.2 \pm 0.2 \mathrm{Ma}$ also resembles the Niut Volcanics phase and could be part of the 4 to $5 \mathrm{Ma}$ igneous event in the Bau-Bungo Range region. 
It is concluded that during the Late Miocene and Pliocene there were three relatively short-lived magmatic phases in West and Central Sarawak and in NW and Central Kalimantan that are now recorded in basic volcanics. The abundance of detrital zircons of these ages in the analysed sediments suggests these basic volcanics were also associated with now completely removed acid igneous rocks. Phase 1 around 6 to $8 \mathrm{Ma}$ is recorded in the earlier Metulang Volcanics and in the Late Miocene age population of sample TB15b. Phase 2 around $5 \mathrm{Ma}$ is also recorded in the older phase of the Metulang Volcanics, the Niut Volcanics and in the younger Pliocene age population of sample TB15b. Phase 3 around $4 \mathrm{Ma}$ is recorded in the Usun Apau Plateau, possible in the Niut Volcanics and in the single zircons of sample TB72. While Phase 1 is nowadays restricted to the Metulang Volcanics in East Kalimantan, it is interpreted that all three phases must have occurred within the Bau area, the Bungo Range or Gunung Penrissen as indicated by the Bau Suite zircons and the Kayan Sandstone pebbles that resemble the Bungo Range sandstone within the TB15b section. The Niut Volcanics south of Gunung Penrissen are the last remains of these phases close to the source area.

The causes for these magmatic phases are not known, but Cullen et al. (2013) and Breitfeld et al. (2019) attributed them to dehydration of an old subducted slab or remelting of arc basalts (which would be from the Mesozoic Paleo-Pacific subduction) associated with deep-rooted basement faults as possible factors contributing to melt generation. Breitfeld et al. (2019) also suggested mantle upwelling in the Miocene into lithospheric thin spots generated by Cenozoic extension possibly as a result of Proto-South China Sea subduction and opening of the South China Sea (Hall and Breitfeld et al., 2017).

\section{CONCLUSIONS}

The obtained detrital zircon data revealed that the two analysed sections in Western Sarawak have a very different provenance. The Kampung Jangkar sediments were entirely derived from the Pueh batholith and were deposited as a sheet-flood or in a braided river system draining to the east. The Petra Jaya sediments were derived by recycling of Bungo Range-type Kayan Sandstone from inferred highlands in the Bau region that are now completely removed. Bau Suite detrital zircons support drainage from this area. Abundant Pliocene zircons indicate acid magmatism in the Pliocene contemporaneous with the basic Niut Volcanics. The acid igneous rocks are interpreted to have now been completely eroded away.

While there is no direct evidence for the depositional age of both sections, a Pleistocene age for the Kampung Jangkar sediments is most likely. The Petra Jaya deposits could be interpreted as contemporaneous to the Jangkar sandstone, but the abundance of Pliocene zircons could also suggest an older Pliocene age.

The provenance of the quartz-rich sediments is highly affected by their catchment and both sections belong to entirely different river systems. Those rivers resemble the present-day drainage but show much higher energy levels and sedimentation rates, possible a function of (Plio-) Pleistocene climate and hinterland exposure.

\section{ACKNOWLEDGEMENTS}

Robert Hall is thanked for continued support and review of the manuscript. Juliane Hennig-Breitfeld provided helpful discussions to improve the manuscript. This project was funded by the SE Asia Research Group of Royal Holloway University of London, which is supported by a consortium of 
oil companies. The Economic Planning Unit of Malaysia and the State Planning Unit of Malaysia made the fieldwork possible, and the Mineral and Geoscience Department Malaysia, Sarawak assisted in the field and with the logistics. Richard Mani Banda and Thomson Galin are therefore especially acknowledged. Martin Rittner and Andy Carter (UCL/Birkbeck College) are thanked for help and support at the LA-ICP-MS facility. An anonymous reviewer is thanked for the final reviewing of the manuscript.

\section{REFERENCES}

Aleva, G.J.J., 1973. Aspects of the historical and physical geology of the Sunda Shelf essential to the exploration of submarine tin placers. Geol. Mijnb. $52,79-91$.

Aleva, G.J.J., 1985. Indonesian fluvial cassiterite placers and their genetic environment. Journal of the Geological Society 142, 815-836.

Aleva, G.J.J., Bon, E.H., Nossin, J.J., Sluiter, W.J., 1973. A contribution to the geology of part of the Indonesian tin belt: the sea areas between Singkep and Bangka Islands and around the Karimata Islands. Geol. Soc. Malaysia, Bull. 6, 257-291.

Allen, G.P., Chambers, J.L.C., 1998. Sedimentation in the modern and Miocene Mahakam Delta, Indonesian Petroleum Association, Jakarta, Indonesia, 236 pp.

Andersen, T., 2002. Correction of common lead in $\mathrm{U}-\mathrm{Pb}$ analyses that do not report $204 \mathrm{~Pb}$. Chemical Geology 192, 59-79.

Andriesse, J.P., 1970. The development of the podzol morphology in the tropical lowlands of Sarawak (Malaysia). Geoderma 3, 261-279.

Batchelor, B.C., 1979. Geological characteristics of certain coastal and offshore placers as essential guides for tin exploration in Sundaland, Southeast Asia. Geol. Soc. Malaysia, Bull. 11, 283-313.

Bladon, G.M., Pieters, P.E., Supriatna, S., 1989. Catalogue of isotopic ages commissioned by the Indonesia-Australia Geological Mapping Project for igneous and metamorphic rocks in Kalimantan, Preliminary Report. Geological Research and Development Centre, Bandung.

Breitfeld, H.T., Davies, L., Hall, R., Armstrong, R., Forster, M., Lister, G., Thirlwall, M., Grassineau, N., Hennig-Breitfeld, J., van Hattum, M.W.A., 2020b. Mesozoic Paleo-Pacific Subduction Beneath SW Borneo: U-Pb Geochronology of the Schwaner Granitoids and the Pinoh Metamorphic Group. Frontiers in Earth Science 8, 568715.

Breitfeld, H.T., Hall, R., 2018. The eastern Sundaland margin in the latest Cretaceous to Late Eocene: Sediment provenance and depositional setting of the Kuching and Sibu Zones of Borneo. Gondwana Research 63, 34-64.

Breitfeld, H.T., Hall, R., Galin, T., BouDagherFadel, M.K., 2018. Unravelling the stratigraphy and sedimentation history of the uppermost Cretaceous to Eocene sediments of the Kuching Zone in West Sarawak (Malaysia), Borneo. Journal of Asian Earth Sciences 160, 200-223.

Breitfeld, H.T., Hall, R., Galin, T., Forster, M.A., BouDagher-Fadel, M.K., 2017. A Triassic to Cretaceous Sundaland-Pacific subduction margin in West Sarawak, Borneo. Tectonophysics 694, 3556.

Breitfeld, H.T., Hennig-Breitfeld, J., BouDagherFadel, M.K., Hall, R., Galin, T., 2020a. OligoceneMiocene drainage evolution of NW Borneo: Stratigraphy, sedimentology and provenance of Tatau-Nyalau province sediments. Journal of Asian Earth Sciences 195, 104331. 
Breitfeld, H.T., Macpherson, C., Hall, R., Thirlwall, M., Ottley, C.J., Hennig-Breitfeld, J., 2019. Adakites without a slab: Remelting of hydrous basalt in the crust and shallow mantle of Borneo to produce the Miocene Sintang Suite and Bau Suite magmatism of West Sarawak. Lithos 344, 100-121.

Burley, S.D., Breitfeld, H.T., Stanbrook, D.S., Morley, R.J., Kassan, J., Sukarno, M., Wantoro, D.W., 2021. A tuffaceous volcaniclastic turbidite bed of Early Miocene age in the Temburong Formation of Labuan, North West Borneo and its implications for the Proto-South China Sea subduction in the Burdigalian. The Depositional Record 7, 111-146.

Collins, D.S., Johnson, H.D., Allison, P.A., Guilpain, P., Damit, A.R., 2017. Coupled 'stormflood' depositional model: Application to the Miocene-Modern Baram Delta Province, north-west Borneo. Sedimentology 64, 1203-1235.

Cottam, M., Hall, R., Sperber, C., Armstrong, R., 2010. Pulsed emplacement of the Mount Kinabalu granite, northern Borneo. Journal of the Geological Society $167,49-60$.

Cottam, M.A., Hall, R., Sperber, C., Kohn, B.P., Forster, M.A., Batt, G.E., 2013. Neogene rock uplift and erosion in northern Borneo: evidence from the Kinabalu granite, Mount Kinabalu. Journal of the Geological Society 170, 805-816.

Cullen, A., Macpherson, C., Taib, N.I., BurtonJohnson, A., Geist, D., Spell, T., Banda, R.M., 2013. Age and petrology of the Usun Apau and Linau Balui volcanics: Windows to central Borneo's interior. Journal of Asian Earth Sciences 76, 372388.

Davies, A.G.S., Cooke, D.R., Gemmell, J.B., van Leeuwen, T., Cesare, P., Hartshorn, G., 2008. Hydrothermal breccias and veins at the Kelian gold mine, Kalimantan, Indonesia: genesis of a large epithermal gold deposit. Economic Geology 103, 717-757.

De Bruyn, M., Stelbrink, B., Morley, R.J., Hall, R., Carvalho, G.R., Cannon, C.H., van den Bergh, G., Meijaard, E., Metcalfe, I., Boitani, L., 2014. Borneo and Indochina are major evolutionary hotspots for Southeast Asian biodiversity. Systematic Biology 63, 879-901.

Doutch, H.F., 1992. Aspects of the structural histories of the Tertiary sedimentary basins of East, Central and West Kalimantan and their margins. BMR Journal of Australian Geology and Geophysics 13, 237-250.

Galin, T., Breitfeld, H.T., Hall, R., Sevastjanova, I., 2017. Provenance of the Cretaceous-Eocene Rajang Group submarine fan, Sarawak, Malaysia from light and heavy mineral assemblages and U$\mathrm{Pb}$ zircon geochronology. Gondwana Research 51, 209-233.

Griffin, W.L., Powell, W.J., Pearson, N.J., O'Reilly, S.Y., 2008. GLITTER: data reduction software for laser ablation ICP-MS. In: Sylvester, P.J. (Ed.), Laser Ablation-ICP-MS in the earth sciences: current practices and outstanding issues Mineralogical association of Canada, short course series 40, 308-311.

Haile, N.S., 1949. Quaternary Deposits, Fossiliferous Mesozoic sediments, and Andesite in the Airfield area, Kuching. GSKL 100/4 (unpubl.).

Haile, N.S., 1974. Borneo. In: Spencer, A.M. (Ed.), Mesozoic-Cenozoic Orogenic Belts, Geological Society of London Special Publication, 4, 333-347.

Hantoro, W.S., 2018. Sunda epicontinental shelf and Quaternary glacial-interglacial sea level variation and their implications to the regional and global environmental change, IOP Conference Series: Earth and Environmental Science. IOP 
Publishing, 012053.

Harahap, B.H., 1987. The petrology of some young subvolcanic and volcanic rocks from West Kalimantan, Indonesia, University of Tasmania, $234 \mathrm{pp}$.

Hart Everett, A., 1878. Notes on the Distribution of the Useful Minerals in Sarawak. Journal of the Straits Branch of the Royal Asiatic Society 13-30.

Heng, Y.E., 1992. Geological Map of Sarawak, 1:500,000. Geological Survey of Malaysia.

Hennig, J., Breitfeld, H.T., Hall, R., Nugraha, A.M.S., 2017. The Mesozoic tectono-magmatic evolution at the Paleo-Pacific subduction zone in West Borneo. Gondwana Research 48, 292-310.

Hennig-Breitfeld, J., Breitfeld, H.T., Hall, R., BouDagher-Fadel, M., 2020. Reply to Discussion: A new upper Paleogene to Neogene stratigraphy for Sarawak and Labuan in northwestern Borneo: Paleogeography of the eastern Sundaland margin. Earth-Science Reviews 202, 103066.

Hennig-Breitfeld, J., Breitfeld, H.T., Hall, R., BouDagher-Fadel, M., Thirlwall, M., 2019. A new upper Paleogene to Neogene stratigraphy for Sarawak and Labuan in northwestern Borneo: Paleogeography of the eastern Sundaland margin. Earth-Science Reviews 190, 1-32.

Heryanto, R., Jones, B.G., 1996. Tectonic development of Melawi and Ketungau Basins, Western Kalimantan, Indonesia. Bulletin Geological Research and Development Centre, Bandung 19, 151-179.

Hutchison, C.S., 2005. Geology of North-West Borneo. Sarawak, Brunei and Sabah., Elsevier, Amsterdam, Netherlands, 421 pp.

Jagodziński, R., Sternal, B., Stattegger, K., Szczuciński, W., 2020. Sediment distribution and provenance on the continental shelf off the Mekong River, SE Vietnam: Insights from heavy mineral analysis. Journal of Asian Earth Sciences 196, 104357.

James, D.M.D., 1984. Geology and hydrocarbon resources of Negara Brunei Darussalam, Brunei Muziurn \& Brunei Shell Petrol. Co., 164 pp.

Johnsson, M.J., Stallard, R.F., Meade, R.H., 1988. First-cycle quartz arenites in the Orinoco River basin, Venezuela and Colombia. The Journal of Geology 96, 263-277.

Labourdette, R., Jones, R.R., 2007. Characterization of fluvial architectural elements using a three-dimensional outcrop data set: Escanilla braided system, South-Central Pyrenees, Spain. Geosphere 3, 422-434.

Liechti, P., Roe, F.W., Haile, N.S., 1960. The Geology of Sarawak, Brunei and the western part of North Borneo: Geological Survey Department, British Territories of Borneo, Bulletin,3, 360 pp.

Ludwing, K.R., 2003. User's Manual for Isoplot 3.00. A Geochronological Toolkit for Microsoft Excel, Berkeley Geochronology Center, Berkeley, CA.

Martin, C.A.L., Turner, B.R., 1998. Origins of massive-type sandstones in braided river systems. Earth-Science Reviews 44, 15-38.

McCabe, P.J., 1987. Facies studies of coal and coal-bearing strata. Geological Society, London, Special Publications 32, 51-66.

Miall, A.D., 1985. Architectural-element analysis: A new method of facies analysis applied to fluvial deposits. Earth Science Reviews 22, 261-308.

Morley, R.J., 1998. Palynological evidence for Tertiary plant dispersals in the SE Asian region in relation to plate tectonics and climate. In Hall, R. 
\& Holloway, J. D. (eds.) Biogeography and Geological Evolution of SE Asia. Backhuys Publishers, Leiden, The Netherlands 211-234.

Morley, R.J., Morley, H.P., 2011. Neogene climate history of the Makassar Straits, Indonesia. Geological Society, London, Special Publications 355, 319-332.

Muller, J., 1968. Palynology of the Pedawan and Plateau Sandstone Formations (Cretaceous Eocene) in Sarawak, Malaysia. Micropaleontology 14, 1-37.

Nagarajan, R., Roy, P.D., Kessler, F.L., Jong, J., Dayong, V., Jonathan, M.P., 2017. An integrated study of geochemistry and mineralogy of the Upper Tukau Formation, Borneo Island (East Malaysia): Sediment provenance, depositional setting and tectonic implications. Journal of Asian Earth Sciences 143, 77-94.

Nemchin, A.A., Cawood, P.A., 2005. Discordance of the $\mathrm{U}-\mathrm{Pb}$ system in detrital zircons: implication for provenance studies of sedimentary rocks. Sedimentary Geology 182, 143-162.

Nguyen, H.H., Carter, A., Van Hoang, L., Vu, S.T., 2018. Provenance, routing and weathering history of heavy minerals from coastal placer deposits of southern Vietnam. Sedimentary Geology 373, 228238.

Page, S.E., Wüst, R.A.J., Weiss, D., Rieley, J.O., Shotyk, W., Limin, S.H., 2004. A record of Late Pleistocene and Holocene carbon accumulation and climate change from an equatorial peat bog (Kalimantan, Indonesia): implications for past, present and future carbon dynamics. Journal of Quaternary Science 19, 625-635.

Pearce, N.J.G., Perkins, W.T., Westgate, J.A., Gorton, M.P., Jackson, S.E., Neal, C.R., Chenery, S.P., 1997. A Compilation of New and Published
Major and Trace Element Data for NIST SRM 610 and NIST SRM 612 Glass Reference Materials. Geostandards Newsletter 21, 115-144.

Percival, T.J., Radtke, A.S., Bagby, W.C., 1990. Relationships among carbonate-replacement gold deposits, gold Skarns, and intrusive rocks, Bau Mining District, Sarawak, Malaysia. Mining Geology 40, 1-16.

Pieters, P.E., Trail, D.S., Supriatna, S., 1987. Correlation of Early Tertiary rocks across Kalimantan. Indonesian Petroleum Association, Proceedings 16th annual convention Jakarta, 1987 I, 291-306.

Prouteau, G., Maury, R.C., Sajona, F.G., Pubellier, M., Cotten, J., Bellon, H., 2001. Le magmatisme post-collisionnel du Nord-Ouest de Bornéo, produit de la fusion d'un fragment de croûte océanique ancré dans le manteau supérieur. Bulletin de la Société Géologique de France 172, 319-332.

Rusmana, E., Sutrisno, Langford, R.P., Keyser, F.d., Trail, D.S., 1993. Geology of the Sambas/Siluas Sheet area, Kalimantan. Map at 1:250000 scale. Geological Research and Development Centre, Bandung.

Sathiamurthy, E., Rahman, M.M., 2017. Late Quaternary paleo fluvial system research of Sunda Shelf: A review. Geol. Soc. Malaysia, Bull. 64, 8192.

Schuh, W.D., Guilbert, J.M., 1990. Gold in Borneo. Eine Disseminationsvererzung vom Typ Carlin als distales Produkt einer porphyritischen Intrusion? Nachrichten Deutsche Geologische Gesellschaft 143, 189-190.

Setiabudi, B.T., Campbell, I.H., Martin, C.E., Allen, C.M., 2007. Platinum group element geochemistry of andesite intrusions of the Kelian region, East Kalimantan, Indonesia: implications of gold 
depletion in the intrusions associated with the Kelian gold deposit. Economic Geology 102, 95108.

Siddiqui, N.A., Mathew, M.J., Ramkumar, M., Sautter, B., Usman, M., Rahman, A.H.A., El-Ghali, M.A.K., Menier, D., Shiqi, Z., Sum, C.W., 2020. Sedimentological characterization, petrophysical properties and reservoir quality assessment of the onshore Sandakan Formation, Borneo. Journal of Petroleum Science and Engineering 186, 106771.

Sircombe, K.N., 2004. AgeDisplay: an EXCEL workbook to evaluate and display univariate geochronological data using binned frequency histograms and probability density distributions. Computers \& Geosciences 30, 21-31.

Sláma, J., Košler, J., Condon, D.J., Crowley, J.L., Gerdes, A., Hanchar, J.M., Horstwood, M.S.A., Morris, G.A., Nasdala, L., Norberg, N., Schaltegger, U., Schoene, B., Tubrett, M.N., Whitehouse, M.J., 2008. Plešovice zircon - A new natural reference material for $\mathrm{U}-\mathrm{Pb}$ and $\mathrm{Hf}$ isotopic microanalysis. Chemical Geology 249, 1-35.

Smyth, H.R., Hall, R., Nichols, G.J., 2008. Significant volcanic contribution to some quartzrich sandstones, East Java, Indonesia. Journal of Sedimentary Research 78, 335-356.

Suttner, L.J., Basu, A., Mack, G.H., 1981. Climate and the origin of quartz arenites. Journal of Sedimentary Research 51.

Tan, D.N.K., 1993. Geology of the Kuching area. West Sarawak, Malaysia.: Geological Survey of Malaysia, Report,16, $161 \mathrm{pp}$.

Tate, R.B., 1991. Cross-border correlation of geological formations in Sarawak and Kalimantan. Bulletin of the Geological Society of Malaysia 28, 63-96.

Tate, R.B., Hon, V., 1991. The oldest rocks in
Borneo; a note on the Tuang Formation, West Sarawak and its importance in relation to the presence of a "basement" in West Borneo. Warta Geologi, Geological Society of Malaysia Newsletter $17,221-224$.

Tera, F., Wasserburg, G.J., 1972. U-Th-Pb systematics in three Apollo 14 basalts and the problem of initial $\mathrm{Pb}$ in lunar rocks. Earth and Planetary Science Letters 14, 281-304.

Thomas, M., Thorp, M., McAlister, J., 1999. Equatorial weathering, landform development and the formation of white sands in north western Kalimantan, Indonesia. Catena 36, 205-232.

Thorp, M., Thomas, M., 1992. The timing of alluvial sedimentation and floodplain formation in the lowland humid tropics of Ghana, Sierra Leone and western Kalimantan (Indonesian Borneo). Geomorphology 4, 409-422.

Thorp, M.B., Thomas, M.F., Martin, T., Whalley, W.B., 1990. Late Pleistocene sedimentation and landform development in western Kalimantan (Indonesian Borneo). Geologie en Mijnbouw 69, 133-150.

van Hattum, M.W.A., Hall, R., Pickard, A.L., Nichols, G.J., 2013. Provenance and geochronology of Cenozoic sandstones of northern Borneo. Journal of Asian Earth Sciences 76, 266-282.

Verstappen, H.T., 1980. Quaternary climatic changes and natural environment in SE Asia. GeoJournal 4, 45-54.

Voris, H.K., 2000. Maps of Pleistocene sea levels in Southeast Asia: shorelines, river systems and time durations. Journal of Biogeography 27, 11531167 .

Wilford, G.E., 1959. Radiocarbon age determinations of quaternary sediments in Brunei and northeast Sarawak. British Borneo Geological 
Survey, Annual Report 16-20.

Wilford, G.E., 1967. The effects of late Tertiary and Quaternary tectonic movements on the geomorphological evolution of Brunei and adjacent parts of Sarawak. J. Trop. Geog. 24, 50-56.

Wilford, G.E., Kho, C.H., 1965. Penrissen area, west Sarawak, Malaysia: Malaysian Geol. Survey, Borneo Region, Rept. 2., 195 pp.

Williams, B.P.J., Hillier, R.D., 2004. Variable alluvial sandstone architecture within the Lower Old Red Sandstone, southwest Wales. Geological Journal 39, 257-275.

Williams, P.R., Harahap, B.H., 1987. Preliminary geochemical and age data from post-subduction intrusive rocks, northwest Borneo. Australian Journal of Earth Sciences 34, 405-416.

Williams, P.R., Johnston, C.R, Almond, R.A., Simamora, W.H., 1988. Late Cretaceous to Early Tertiary structural elements of West Kalimantan. Tectonophysics 148, 279-298.
Witts, D., Hall, R., Nichols, G., Morley, R., 2012. A new depositional and provenance model for the Tanjung Formation, Barito Basin, SE Kalimantan, Indonesia. Journal of Asian Earth Sciences 56, 77 104. Wolfenden, E.B., 1965. Bau Mining District, West Sarawak, Malaysia, part I. Bau. Geological Survey of Malaysia, Borneo Region, Bulletin 7, $147 \mathrm{pp}$.

Wolfenden, E.B., Haile, N.S., 1963. Semantan and Lundu area, West Sarawak: British Borneo Geological Survey Report, 1, 159 pp.

Wurster, C.M., Rifai, H., Zhou, B., Haig, J., Bird, M.I., 2019. Savanna in equatorial Borneo during the late Pleistocene. Scientific reports 9, 1-7. 